\title{
Non-tariff measures, quality, and exporting: evidence from microdata in food processing in Ukraine*
}

\author{
Veronika Movchan† Oleksandr Shepotylo $\ddagger$ and Volodymyr Vakhitov ${ }^{\S}$
}

May 28, 2019

\begin{abstract}
Domestic non-tariff measures (NTM) influence firm's production and import decisions. We introduce NTMs into a model with heterogeneous firms. NTMs increase the cost of production and play a role of a positive demand shifter. Interplay of these two factors leads to ambiguous impact of NTMs on extensive and intensive margins of trade. We test predictions of the model by looking at food-processing firms in Ukraine in 2008-2013. Evidence shows that more SPS regulations on inputs in upstream industries leads to exports of better quality products. At the same time mandatory certifications have a negative impact on quality by limiting access of domestic firms to new technologies and equipment.
\end{abstract}

Key words: NTM, quality, import, export, food, heterogeneous firms

JEL codes: L11, F12, O14

\footnotetext{
*This paper is written with financial support by "Non-tariff barriers, food safety and international food trade" joint project of Norwegian Institute of International Affairs (NUPI), Norwegian University of Life Sciences, and Kyiv School of Economics (KSE) funded by the Research Council of Norway (Contract no. 216742/O10). Volodymyr Vakhitov is thankful for the support to the German Federal Ministry of Education and Research (BMBF), Germany, the grant number is 01DK17054, distributed under "UaFoodTrade". We would like to thank Arne Melchior, Hege Medin, Maren Bachke for their help and support. We also thank participants of NUPI, ETSG, and SITE conferences. All remaining errors are ours.

${ }^{\dagger}$ Institute for Economic Research and Policy Consulting, movchan@ier.kiev.ua

${ }^{\ddagger}$ Aston University, o.shepotylo@aston.ac.uk

${ }^{\S}$ Kyiv School of Economics, vakhitov@kse.org.ua
} 


\section{Introduction}

Non-tariff measures (NTM) play a substantial role in determining what and how firms produce. Domestic NTMs set standards for quality and safety of imported inputs, which has crucial implications for production processes of firms and their decisions on quality, quantities, and prices of final goods. NTMs are important because they are often more trade-restrictive than tariffs. ${ }^{1}$ As a result, domestic NTMs crucially impact firms' competitiveness in international markets, influencing their import and export decisions. It is even more important for firms in emerging and transition countries, which require good access to foreign technologies and equipment.

NTMs also have an essential role in shaping demand, in particular for food products. Consumers are highly concerned about food quality and safety. According to 2014 Food \& Health Survey, $90 \%$ of Americans consider the food taste as the major factor influencing their buying decision, while only $73 \%$ mention its price. 2015 Pew Global Attitudes and Trends Survey finds that $61 \%$ of Germans name lower United States (US) food, environmental, and auto safety standards as the most important reason for rejecting a free trade agreement with the US. Responding to these concerns, governments and food industry groups introduce labeling to inform about food ingredients, regulate handling and sanitation to insure food safety, and set technological restrictions on the use of certain ingredients (Sunding, 2003).

By shifting supply and demand, effects of NTMs on trade are ambiguous. On the one hand, these standards and regulations serve to protect consumers from fraudulent, low-quality products and alleviate the asymmetric information problem, rewarding sellers of high quality products with higher demand. On the other hand, they increase market power of domestic producers, reduce product variety available for consumers, and generate extra costs of testing and monitoring food-processing firms (Gardner, 2003). There is also an issue of mutual recognition of standards set in different countries, adding extra burden on food producers who export to multiple countries.

Most studies that looked at the effects of NTMs have found a negative effect on trade values (Otsuki et al., 2001; Disdier et al., 2008; Crivelli and Gröschl, 2016). For example, Disdier et al. (2008) have shown a strong negative effect of NTMs on exports from developing countries. However, Anders and

\footnotetext{
${ }^{1}$ Looi Kee et al. (2009) find that in 2003 the simple average ad valorem equivalent NTM was 10 percent, while the average ad valorem tariff was only 3.7 percent. Tariff data are trade-weighted average most favoured nation (MFN) tariff from the World Bank databank.
} 
Caswell (2009), who investigated the effect of the Hazard Analysis Critical Control Points (HACCP) food safety standard on seafood imports, found the negative effect for exports from developing countries and positive effect for exports from developed countries. Similarly, Hoekman and Nicita (2011) found that NTMs have a positive effect on trade in more technologically advanced sectors and negative effect in agriculture. Focusing on the maximum residue level (MRL) regulation, Xiong and Beghin (2014) disentangled the effect into demand and supply and confirmed that the demand effect of the food safety measures is positive, while the supply effect is negative. Moreover, they found that exporters from developing countries are more constrained by MRL. Finally, Ferro et al. (2015) found that stricter MRL regulations have a negative effect on extensive margins of exports, while the effect on intensive margins was not significant.

There is also emerging research on quality and trade. Crozet et al. (2012) analyze the effect of quality on price in French champagne industry and demonstrate that firms' heterogeneity in quality is a very important determinant of their market shares: having a better quality pays off because of a higher price and larger market share. Khandelwal (2010) and Amiti and Khandelwal (2013) introduced a methodology to measure quality based on trade data. Fan et al. (2015), Bas and StraussKahn (2015), and Fan et al. (2018) show that trade liberalization, measured as a reduction in MFN tariffs, lead to export quality upgrading of Chinese firms as a result of China accession to the World Trade Organization (WTO). Curzi et al. (2015) demonstrated that import competition leads to quality upgrading of varieties close to the top of the technology frontier.

Our work is related to Curzi et al. (2018) who found that NTMs significantly limit exports at extensive and intensive margins. At the same time, more stringent NTM measures induce quality upgrading, which is more pronounced for small firms. It is also related to Olper et al. (2017) who found that trade liberalization of intermediate inputs in food industry had a positive impact on productivity of French and Italian firms. Our analysis, however, is focused on the impact of domestic NTMs on trade and quality of domestically produced varieties. This question is important for domestic policymakers, who have direct influence on domestic NTM regulations and need to design a good policy from wide variety of NTM tools.

We build a partial equilibrium model with heterogeneous producers that captures effect of NTMs through their impact on cost of production and quality, which in turn shifts supply and demand schedules. The model predicts that domestic NTMs restrict the use of imported inputs, which influences 
quality and value of exported final goods. The impact varies with firm productivity. For instance, setting minimum quality requirements has higher impact on less productive firms, causing the least productive firms to stop exporting, while more productive ones to upgrade their quality.

We test the predictions of the model using the data on Ukrainian firms in food-processing industry (NACE Rev1.1, Section 15: Manufacture of food products and beverages) in 2008-2013. We refer to this episode as NTM trade liberalization as we study the effect of streamlining of Ukraine's food safety system in the process of the WTO accession. The reform of food safety measures meant several parallel processes: 1) abolishment of duplication of controls; 2) abolishment of mandatory certification (Soviet style, outdated "fixed-recipe" standards); 3) a switch from the control over final products towards the control over process (HACCP). We are able to capture the first two reforms by measuring presence and intensity of parallel sanitary and phytosanitary (SPS) measures and abolishment of the system of mandatory certification. The switch to HACCP in Ukraine has been slow, so we do not consider its impact on food industry during the investigated period.

Combining firm-level and customs data on exports and imports, we study how NTMs influence quantity and quality of trade at extensive and intensive margins. To measure NTMs, we use a unique dataset, constructed by Movchan (2015) that records veterinary, sanitary, phytosanitary, ecology controls, and mandatory certifications from the Ukrainian legislation at 10 digit level of the Ukrainian trade classification. These measures are parts of the customs border control system and are applied towards imported goods. We further construct upstream measures of trade restrictiveness caused by NTMs and estimate the impact of those measures on firms' imports and exports along quantity, price, and quality-related margins. Our constructed input SPS measures capture presence and intensity of NTM controls in the upstream industries - duplication of controls results in higher values. For mandatory certifications higher number represents more extensive use within a harmonized system (HS) 4 digit product group.

Our findings are as follows. First, we find evidence that an increase in the number of SPS regulations on imported inputs in food processing leads to higher export prices and higher quality of exported food products. The impact is driven by sanitary measures, which play a prominent role in SPS regulations across all food sub-industries. Second, increased quality comes at a price of the reduction in export both at extensive and intensive margins. Third, the introduction of mandatory certifications reduces price and quality of final goods. It indicates that the system of mandatory certifications, which had 
inherited outdated approach to technical regulations, does not serve its main purpose - it limits the access of Ukrainian food processing firms to modern technologies and equipment.

These results are important for policymakers who aim to improve food quality without limiting competitiveness of food exporters. Focusing on SPS measures that are designed to address health and safety concerns of consumers, especially targeting quality of ingredients, would achieve these goals if combined with replacing the outdated Ukrainian system of mandatory certifications with modern forms of technical regulations.

The structure of the rest of the paper is as follows. Next section presents and discusses our NTM data. Section 3 introduce a model. Section 4 describes firm-level data that we use in our analysis. Section 5 presents our results on the effect of NTMs on trade and quality. Section 6 concludes.

\section{Liberalization of Ukrainian system of non-tariff measures in 2008- 2013}

We refer to 2008-2013 as the episode of NTM liberalization. Ukraine's NTMs has been under transformation for several decades, gradually evolving from the Soviet Union mandatory standards (GOST) towards the WTO system, which is also compatible with the European Union (EU) standards. Under the old system, SPS legislation was focused on the outcome control measures rather than on hazards and prevention. There was the duplication of control functions. On the one hand, there are controls implemented by specialized services: the State Service of Veterinary Medicine, the State Service of Plant Quarantine and the State Sanitary-Epidemiological Service. On the other hand, there were the State Standards Committee (SSC) inspections through the so-called mandatory certification.

Certifications establish mandatory requirements for product, service, or production processes. According to the WTO Working Party Report before the WTO accession: “... notwithstanding changes to the Law "On Quality and Safety of Food Products", and the clarifications offered by the representative of Ukraine to the Working Party, duplication of supervisory and controlling functions between the sanitary service, veterinary service, and the State Standards Committee persisted. Importers of food products continued to be required by Ukrainian authorities to complete multiple testing procedures

in order to establish compliance with overlapping regulations of the veterinary service and the State Standards Committee. Further, the list of imported food products subject to mandatory certification 
by the State Standards Committee had not been eliminated despite Ukraine's assurances that it would be." (WTO (2008), Report of the Working Party on the Accession of Ukraine to thee World Trade Organization, WT/ACC/UKR/1).

International institutions supporting the regulatory reforms in Ukraine also criticized the mandatory certification as an inappropriate form of food safety control. According to the International Finance Corporation (IFC), " compulsory certification in Ukraine virtually fixes the food recipe in stone, but it does little to ensure real consumer safety since it does not provide a real system to monitor hazards on an ongoing basis, nor a traceability mechanism" (IFC, 2008). As a part of the WTO accession commitments, Ukraine explicitly committed "removing any authority for the State Standards Committee to require testing or certification of any imported food product. As a result, imported food products would be subject to testing and certification only by the sanitary service or veterinary service, as appropriate" (Art. 313, WTO, 2008). After Ukraine became a member of the WTO in 2008, the process of NTM liberalization has accelerated and the duplication of functions between certifications and SPS related controls was gradually removed (Movchan, 2015).

To measure the process of NTM liberalization, we rely on the Ukrainian NTM data collected by and described in Movchan (2015). Our focus is on NTMs designed to safeguard life and health of people, animals, and plants. These measures include veterinary, sanitary, phytosanitary, and ecology controls, which are jointly called SPS measures. We also measure mandatory certifications, which are remnants of the old, outdated system of controls. These measures are parts of the customs border control system and are applied towards imported goods.

NTM provisions are taken directly from the Ukrainian legislation. Table 1 describes the legal sources considered. Data is collected at 10 digit classification of product lines (TS10), which makes the Ukrainian NTM data a unique tool to look at the effect of NTMs at micro-level. NTMs are coded as binary variables, taking the value of 1 if type $k$ NTM is applied and 0 otherwise. ${ }^{2}$ Data is further aggregated to the level of HS 4-digit product lines as the share of lines with NTMs: $N T M_{H S 4, t}^{k}=$ $\frac{1}{N_{H S 4}} \sum_{T S 10 \in H S 4} N T M_{H S 10, t}^{k}$, where $k=\{$ Veter, Ecol,Sanit,Phyto,Cert $\}, N T M_{T S 10, t}^{k}$ are binary NTM indicators at 10 digit level and $N_{H S 4}$ is the number of TS10 digit lines within an HS 4-digit category. Finally, using the HS to the International Standard Industrial Classification (ISIC) and ISIC to the Statistical Classification of Economic Activities in the European Community (NACE)

\footnotetext{
${ }^{2} \mathrm{~A}$ limitation of this approach is its inability to capture how restrictive and costly a measure is.
} 
Table 1: Ukrainian laws and regulations on non-tariff measures

\begin{tabular}{ll}
\hline \hline Type of NTM & Basic legislation \\
\hline Veterinary & Law on Veterinary Medicine \\
Sanitary & Law on Food Safety \\
Phyto-sanitary & Law on Quarantine of Plants \\
Ecology & Law on Environment Protection \\
Certification & Orders of State Committee on Technical Regulation and \\
& Consumer Policy on List of Products of Mandatory Certification \\
& Orders of State Standardization Office on List of Products of \\
& Mandatory Certification \\
\hline
\end{tabular}

concordances available from the World Integrated Trade Solutions (WITS) website and the Eurostat / RAMON service, we aggregate NTM measures to the level of NACE1.1 3-digit food sub-industries, computing simple averages of all TS 10 digit NTMs. ${ }^{3}$

Figure 1 presents NTM in the nine food sub-industries in 2007-2013. There were two major changes to the NTM legislation - in 2009 and 2012. The WTO membership in 2009 created an important push for reforms to reduce a number of NTMs, as Ukraine committed to align the trade regime with WTO rules. However, the process was not linear, and some areas experienced an increase in the number of regulations in 2012, when the government increased the number of lines subject to sanitary and veterinary controls after implementing a new Customs Code. The number of lines subject to veterinary controls has increased in meat and fish sub-industries. This was to a large extent a step towards harmonization of Ukrainian and international SPS regulations. The number of goods subject to mandatory certifications on the other hand has been constantly declining in all sub-industries throughout the entire period.

\section{A model of heterogeneous firms with quality and NTM constraints}

\subsection{Model setup}

There are two countries, Foreign and Home. Consumers in both countries derive utility from quality and quantity consumed. Product quality is observable and characterized by a scalar that modifies consumed

\footnotetext{
${ }^{3}$ Description of the matching procedure is available from the authors upon request.
} 
Figure 1: NTM in $2007-2013$

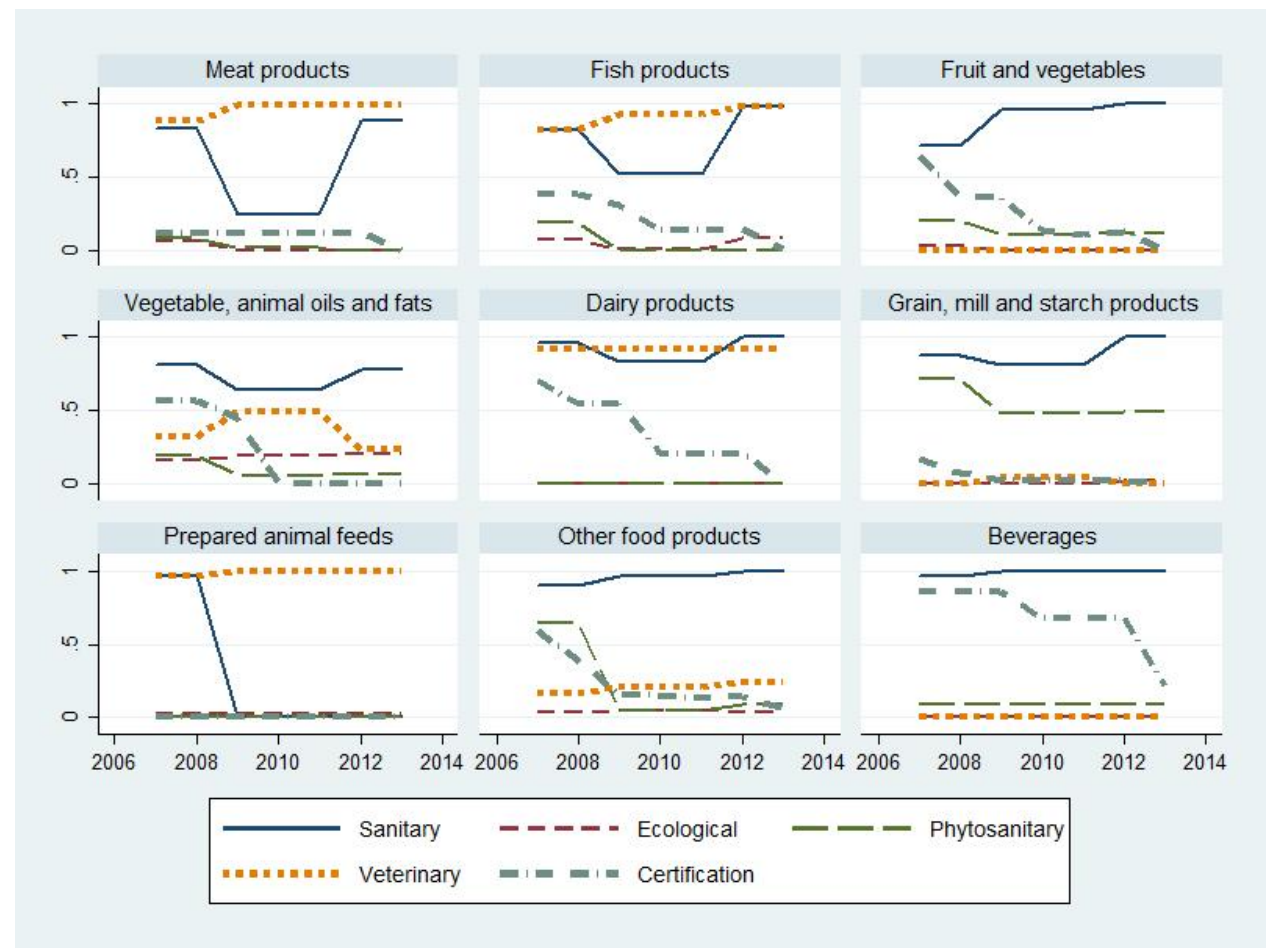

This figure reports the share of tariff lines within food processing sub-industries affected by sanitary, veterinary, phytosanitary, ecological measures, and mandatory certifications in Ukraine in 2007-2013. Correspondence between HS and NACE is constructed using the mapping available from the World Integrated Trade Solutions (WITS) website and the Eurostat / RAMON service. 
quantity in a multiplicative fashion. We focus on the partial equilibrium analysis of Home firms, operating in a monopolistically competitive food industry. Firms are heterogeneous in productivity, which is modeled as in Melitz (2003). Firm quality and its relationship with fixed and variable cost of production is modeled as in Hallak and Sivadasan (2013). Given their productivity and aggregate market statistics at Home and in Foreign, firms make decisions on how much to produce, what type of technology to use, what level of quality to select, and whether to export or not.

We further introduce trade policy into this model as follows. Home government regulates domestic market with tariff and non-tariff measures, which may directly or indirectly influence quality decisions: regulations have a differential impact on firms with different levels of productivity, directly affecting firms that do not meet the quality criteria, forcing them to change their optimal choice of inputs, and indirectly affecting firms that meet the quality requirements through changes in industry-wide aggregates.

\section{Consumer}

A representative consumer derives utility according to the following function

$$
U=\left[\int_{\omega \in \Omega}(\lambda(\omega) q(\omega))^{\frac{\sigma-1}{\sigma}} d \omega\right]^{\frac{\sigma}{\sigma-1}}, \sigma<1
$$

where $\omega$ indexes varieties, $\Omega$ represents the set of available products, $q(\omega)$ is consumption level, and $\sigma$ is constant elasticity of substitution across varieties. A one-dimensional variable $\lambda(\omega)$ characterizes product quality that aggregates attributes valued by consumers. ${ }^{4}$ Given prices $p=\{p(\omega)\}, \omega \in \Omega$, the consumer with food expenditure level $R$ maximizes (1) subject to the budget constraint ${ }^{5}$

$$
\int_{\omega \in \Omega} p(\omega) q(\omega)=R
$$

Utility maximization yields the following demand for variety $\omega$

$$
q(\omega)=\lambda(\omega)^{\sigma-1}\left(\frac{p(\omega)}{P}\right)^{-\sigma} R / P
$$

\footnotetext{
${ }^{4}$ For food products these attributes include food safety and taste, stemming from the choice of the technological process and quality of used ingredients.

${ }^{5}$ We take the aggregate expenditures on food as exogenously given, but this decision can be modeled as a two-tier utility function with the upper CES utility preferences. In equilibrium, the consumer allocates a fixed share of his budget to consumption of food.
} 
where $P$ is the quality-adjusted price index

$$
P=\left(\int_{\omega \in \Omega}(p(\omega) / \lambda(\omega))^{1-\sigma} d \omega\right)^{1 /(1-\sigma)}
$$

\section{Production technology}

Firms are heterogeneous in productivity $\varphi$, which they draw from a known distribution with c.d.f. $G(\varphi)$, upon paying the entry cost $f^{E}$. Our assumptions about fixed and variable costs closely follows Hallak and Sivadasan (2013). To produce, a firm incurs a fixed cost, which increases with quality

$$
F(\lambda)=F_{0}+f \lambda^{\alpha}
$$

where $F_{0}$ is a fixed cost component that does not depend on quality, $f$ is a constant, and $\alpha>0$ is a parameter that represents the extent of an increase in cost of investment in quality.

Higher quality also requires use of better inputs and more sophisticated technology, which increases marginal cost of production (for simplicity marginal cost do not vary with output)

$$
c(\lambda, \varphi)=\frac{\kappa}{\varphi} \lambda^{\beta}
$$

where $\kappa$ is a scaling parameter, and $0 \leq \beta<1$ captures the strength of the effect of quality on the marginal cost. ${ }^{6}$ As it turns out, the relationship between quality and productivity crucially depends on the relative size of elasticities of marginal and fixed costs with respect to quality.

\subsection{Optimal quality and trade liberalization}

A firm can sell its product to Foreign after paying a fixed export cost, $f^{X}$, and variable trade $\operatorname{cost} \tau$. The firm solves

$$
\pi(\varphi)=\max _{p, \lambda, I_{x}, p_{x}}[p-c(\lambda, \varphi)] q(p, \lambda)+I_{x}\left\{\left[p_{x}-c(\lambda, \varphi)\right] q_{x}\left(p_{x}, \lambda\right)-f^{X}\right\}-F(\lambda)
$$

where $q_{x}$ and $p_{x}$ are quantity and price in Foreign, $I_{x}$ is an indicator variable that takes value of 1 if the firm exports and 0 otherwise. The firm optimally chooses quality level $\lambda$, which we assume is

\footnotetext{
${ }^{6} \beta<1$ is required for a non-zero quality as the solution of the profit maximization problem. If marginal cost grows too fast, firms would prefer not to spend on quality upgrading.
} 
the same in both markets. ${ }^{7}$

Solving for optimal quantity at Home and Foreign yields

$$
q=\left(\frac{\sigma-1}{\sigma}\right)^{\sigma} \frac{R}{P^{1-\sigma}}\left(\frac{\kappa}{\varphi}\right)^{-\sigma} \lambda^{\sigma(1-\beta)-1}
$$

and

$$
q_{x}=\left(\frac{\sigma-1}{\sigma}\right)^{\sigma} \frac{\tau^{1-\sigma} R^{*}}{P^{* 1-\sigma}}\left(\frac{\kappa}{\varphi}\right)^{-\sigma} \lambda^{\sigma(1-\beta)-1}
$$

Depending on whether $\sigma(1-\beta)>1$ or not, quantities consumed in Home and Foreign either increase or decline with quality. Given elasticity of substitution, if marginal cost is not sensitive to quality ( $\beta$ close to 0), consumers demand more food when quality increases. However, if quality leads to almost one-to-one increase in marginal cost ( $\beta$ close to 1$)$, consumers would prefer less for higher quality food products. This happens because the positive gains from consumer demand due to higher quality are opposed by the negative effects of increasing price due to higher marginal cost. Foreign quantity also depends on variable trade costs and Foreign market size.

Optimal quality is given by

$$
\lambda^{*}(\varphi)=\left(\frac{1-\beta}{\alpha f}\left(\frac{\sigma-1}{\sigma}\right)^{\sigma}\left(\frac{\varphi}{\kappa}\right)^{\sigma-1} W\left(I_{x}\right)\right)^{\frac{1}{\rho}}
$$

where $W\left(I_{x}\right)=\frac{R}{P^{1-\sigma}}+I_{x} \tau^{1-\sigma} \frac{R^{*}}{P^{* 1-\sigma}}, R^{*}$ and $P^{*}$ are Foreign expenditures and price level, and $\rho=\alpha-(1-\beta)(\sigma-1)$. When $\alpha>(1-\beta)(\sigma-1)$ firms with higher productivity also select better quality. The assumption is more likely to hold when love for variety is stronger ( $\sigma$ is close to 1$)$, or when marginal cost is more dependent on quality ( $\beta$ is close to 1 ), or when fixed costs are growing faster with quality ( $\alpha$ is high). ${ }^{8}$ Given empirical observations that more productive firms produce higher quality products and that trade liberalization improves quality of exports (i.e. Amiti and Khandelwal, 2013),

\footnotetext{
${ }^{7}$ There are evidence that firms differentiate quality across countries (Manova and Zhang, 2012). However, our main focus is on the effect of NTM policies at Home on domestic firms. Therefore, we make this simplifying assumption, which does not change main qualitative predictions.

${ }^{8}$ Interestingly, optimal quality level decline with $\alpha$ if $\alpha>(1-\beta)(\sigma-1)$, assuming that $\ln \lambda>0$. Derivative of $\lambda^{*}$ with respect to $\alpha$ is

$$
\frac{d \lambda^{*}}{d \alpha}=\frac{-\ln \lambda \times \lambda^{\alpha-(1-\beta)(\sigma-1)}-\frac{1-\beta}{\alpha^{2} f} \frac{\sigma-1}{\sigma}\left(\frac{\varphi}{\kappa}\right)^{\sigma-1} W\left(I_{x}\right)}{[\alpha-(1-\beta)(\sigma-1)] \lambda^{\alpha-(1-\beta)(\sigma-1)-1}}
$$
}


we make the following assumption.

\section{Assumption 1}

$$
\alpha>(1-\beta)(\sigma-1)
$$

Proposition 1 (Trade liberalization and quality) Suppose that good's quality produced by a firm does not vary across markets and assumption 1 holds.

1. Conditional on exporting, opening-up to trade, which reduces trade costs $\tau$, improves firm-level optimal quality $\lambda^{*}$.

2. Reduction in fixed costs $f$ increases optimal quality $\lambda^{*}$.

3. Increase in productivity $\varphi$ increases optimal quality $\lambda^{*}$.

Proof of part 1: Given productivity level, exporters choose higher quality than firms with the same productivity in the autarky due to larger market size

$$
\frac{\lambda_{e x p}^{*}}{\lambda^{*}}=\left[1+\tau^{1-\sigma} \frac{R^{*} P^{*(\sigma-1)}}{R P^{(\sigma-1)}}\right]^{\frac{1}{\rho}}
$$

Since trade liberalization reduces $\tau$, the ratio of quality under free trade and autarky increases. Parts 2 and 3 directly follow from 8. Q.E.D.

The proposition establishes conditions for trade liberalization having a positive effect on quality of produced goods. First, trade liberalization that reduces variable and fixed trade costs triggers quality upgrading. Second, increase in productivity leads to quality upgrading.

From part 3 of the proposition it follows that once a country reduce its trade barriers, it encourages more imports of higher quality. In the case of Ukraine, trade liberalization resulted in lower tariffs and gradual elimination of old system of sanitary, phytosanitary, and technical controls, inherited from the Soviet Union system of mandatory standards (GOST). In this way, Ukrainian NTMs became more in line with WTO and EU standards and regulations. Shepotylo and Vakhitov (2015) have shown that the Ukrainian trade liberalization led to increase in productivity of manufacturing firms. Based on this fact, we develop the following corollary, that easily follows from Proposition 1. 
Corollary 1 (Trade liberalization of inputs and quality of exports) Trade liberalization that lowers tariffs and reduces NTM incurred trade costs on imported inputs increases productivity of firms that use imported intermediate inputs and, as a result, increases quality of exports.

In our sample approximately a third of firms import and, as we demonstrate in Section 5, the most important items of import are imported machinery and ingredients (fats and oils, cocoa, vegetables, fruits, and nuts).

\subsection{A minimum quality restriction and heterogeneous firms}

Consider the effect of imposing a minimum quality restriction on the firm's optimal quality decision. Initially (dashed line), all firms are sorted into 'exiters' (Region I), domestic (Regions II-IV), and exporting firms (Region V), according to their productivity and quality choices presented in Figure 2. As long as $\alpha>(1-\beta)(\sigma-1)$, quality monotonically increases with productivity and there is one-to-one mapping from productivity to quality. There is also discontinuity in quality for marginal exporters due to fixed costs of exporting.

Suppose that the domestic government sets a minimum quality restriction, $\lambda_{N T M}$. We rule out the trivial case when the constraint is not binding for any firm and consider the case when $\lambda^{*}\left(\varphi_{d}\right)<$ $\lambda_{N T M}<\lambda^{*}\left(\varphi_{\text {exp }}\right)$. Keeping the industry aggregates constant, this policy does not change behavior of 'exiters', local firms from Region 4, and exporters. However, for firms located in Regions II and III there is a dilemma - either to exit the industry or to upgrade their quality to $\lambda_{N T M}$ (red line in Figure 2).

Proposition 2 (Minimum quality requirements and firms) Introduction of NTM restrictions induces exit of firms with low productivity (Region II in Figure 2) and quality upgrading of firms with medium range productivity (Region III).

Proof: See Appendix A2. 
Figure 2: Quality and productivity with NTM

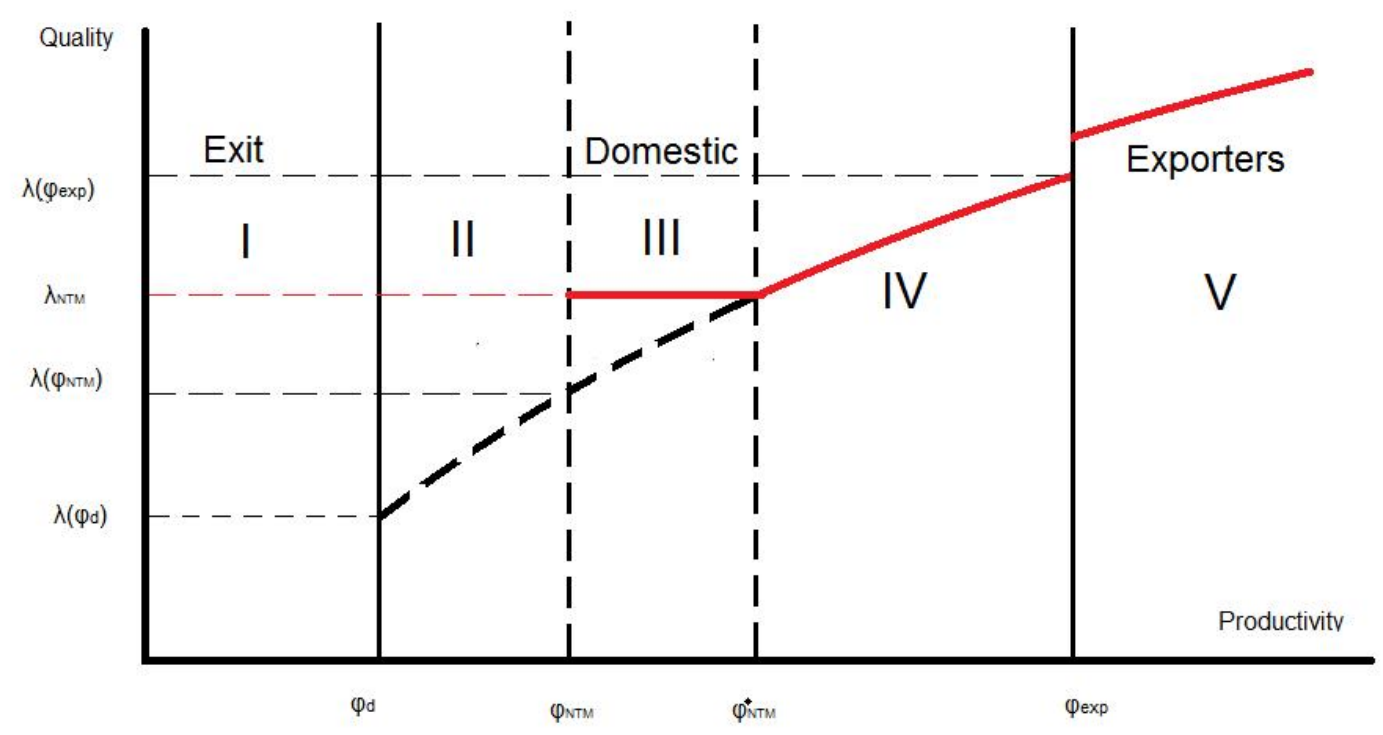

\subsection{Input factors, quality, and NTM}

To produce better quality, a firm requires better factors of production and better inputs. We parsimoniously capture this idea by differentiating labor by skills, capital by vintage, and material inputs by quality. Factor and intermediate goods markets are perfectly competitive, so the factor and input prices are given by

$$
w=\underline{w} \times \lambda^{b_{h}}, r=\underline{r} \times \lambda^{b_{k}}, p_{m}=\underline{p_{m}} \times \lambda^{b_{m}}
$$

where $w, r$, and $p_{m}$ are prices of labor $h$, capital $k$, and intermediate goods $m ; b_{i}>0, i=\{L, K, M\}$ are parameters that capture costs of quality upgrading, and underscored factor prices represent the baseline quality inputs.

A firm has the following production function

$$
q=h^{\alpha_{h}} k^{\alpha_{k}} m^{\alpha_{m}} \exp (\omega)
$$


where $q$ is physical quantity of production that depends only on quantity of inputs; $h, k$ and $m$ are physical quantities of inputs, and $\exp (\omega)=\varphi$ is productivity. In our model we assume that the marginal cost does not vary with output, implying that $\sum_{i} \alpha_{i}=1$. This assumption is in agreement with our estimation of production function presented in the next section. Out of 9 food processing subindustries, we can not reject this assumption for 8 industries. Production of vegetables has decreasing returns to scale because it uses fixed factor - land, that is not accounted for in our estimation procedure.

Cost minimization yields

$$
C(q, \varphi, \lambda)=q \times \frac{\kappa}{\varphi} \lambda^{\beta}
$$

where $\kappa=\frac{\underline{w}^{\alpha}{ }^{\alpha} \underline{r}^{\alpha} \times \underline{p}_{m}{ }^{\alpha_{m}}}{\alpha_{h}^{\alpha_{h}} \alpha_{k}^{\alpha_{k}} \alpha_{m}^{\alpha_{m}}}$ and $\beta=\sum_{i} \alpha_{i} b_{i}$, which brings the already introduced unit cost function

$$
c(\varphi, \lambda)=\frac{\kappa}{\varphi} \lambda^{\beta}
$$

Given our assumption $\sum_{i} \alpha_{i}=1, b_{i}<1 \forall i \in\{h, k, m\}$ it is also the case that $\beta<1$.

Factor demand for intermediate inputs is given by

$$
m=q w^{\alpha_{h}} r^{\alpha_{k}} p^{\alpha_{m}-1}
$$

Prices for intermediate inputs are driven by optimal quality choice $p_{m}(\lambda)=\underline{p_{m}} \times \lambda^{b_{m}}$. We assume that local and foreign suppliers are competing in the perfectly competitive intermediate goods market (i.e. Eaton and Kortum, 2002). $p_{m}(\lambda)=\min \left\{p_{m}^{d}(\lambda), p_{m}^{f}(\lambda) \times \tau\right\}$, where $p_{m}^{d}$ is a price of the best local supplier, $p_{m}^{f}$ is the price of the best foreign supplier, and $\tau$ is the variable trade cost.

\section{Data}

This section discusses data sources and variables used in the analysis. Detailed description of data sources and variables is also provided in Appendix A.4.

\section{Production}

We define food processing industry as all firms reporting their main economic activity as NACE1.1 Section 15: Manufacture of food products and beverages. The industry is further divided into 9 sub- 
industries, corresponding to NACE1.1 3 digit categories of food industry. Heterogeneity in productivity plays an important role in further analysis. We use total factor productivity (TFP) as the productivity measure. Data for estimating the productivity comes from statistical forms all food processing firms have to submit to the State Statistical Service of Ukraine (Ukrstat). Output is measured as total sales revenues net of excise and other indirect taxes; this measure comes from the Financial Results Statement. The same statement also contains data on material costs, which is measured as the firm's expenditures on materials, supplies, and utilities. The Balance Sheet statement is the source of the data on the end-of-year value of fixed assets, which we use as our measure of capital. Employment, which is reported along with the Balance Sheet statement, is measured as full-time equivalent of the labor force, and calculated as the average number of employees weighted by their time involvement. We also use investments in fixed assets, which is taken from the Enterprise performance statement. Finally, each firm has an indicator of the industry code (at the level of 3 digit of NACE classification).

The values of the capital and capital investments are deflated with economy-wide producer price index (PPI), whereas material costs are deflated with consumer-price index (CPI). ${ }^{9}$ We then add very detailed annual statements of firm-level manufacturing output by product groups, which contain both value of output and quantity in kilograms, and obtain separate estimates of output price indices at the level of six digit of the statistical classification of products by activity (CPA), which are used for deflating revenue and for estimating the quantity-based TFP. In the process of price determination we drop extremely high and low values with understanding that aggregation at the level of six digits covers substantial heterogeneity between physical outputs.

\section{Estimation of production function and TFP}

The total factor productivity is estimated separately for each 3-digit NACE1.1 group, which we refer to as 9 food sub-industries (i.e. meat sub-industry, fish sub-industry etc.) using a sample of food processing firms in 2004 to $2013 .^{10}$

\footnotetext{
${ }^{9}$ We do not have data on input prices or input price deflators. Therefore, we introduce a measurement error in estimation of TFP. This may lead to attenuation bias and underestimation of productivity for more productive firms, which use better quality inputs (see De Loecker et al. (2016) and Olper et al. (2017)). However, this measurement error is of the second order of magnitude. We address the main source of measurement error in TFP estimation because we use quantity of output as our dependent variable. Also, we use TFP in 2008 only to reduce measurement error over different time periods and address endogeneity of productivity in further analysis.

${ }^{10}$ The longer time dimension is taken to evaluate the production function parameters in order to get more precise estimates.
} 
We estimate production function for both quantity and revenue based measure of output based on Olley and Pakes (1996) (OP) with correction suggested in Ackerberg et al. (2015). ${ }^{11}$ More detailed presentation of the methodology and estimated parameters of production function are given in Appendix A.3.

Figure 3 shows dynamics of TFP in 2007-2013. The solid line represents quantity-based TFP, while the dashed line represents revenue-based TFP. In each case, we trim the bottom 1 percent and top 1 percent of TFP values. The two TFP measures demonstrate similar patterns, still there are quite important differences, since the correlation between the two measures is 0.77 . In what follows we use the quantity based TFP measure, because it better measures technical efficiency and separate it from quality and price effects.

Figure 3: Evolution of TFP in food industry in Ukraine, 2007-2013 by food sub-industries

TFP by industry
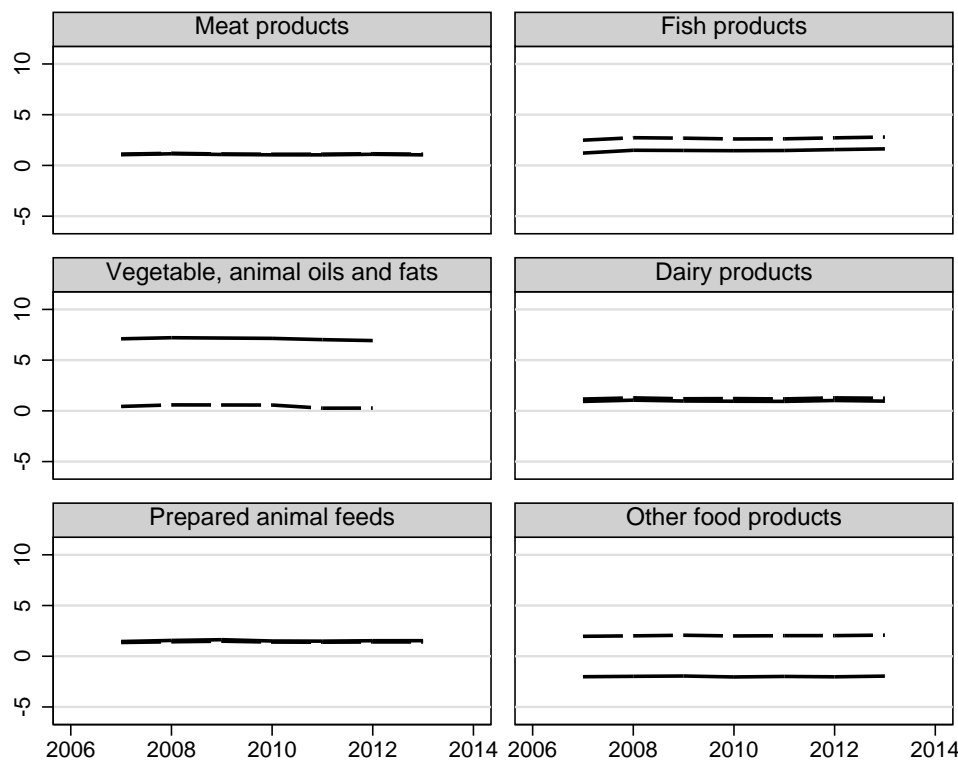
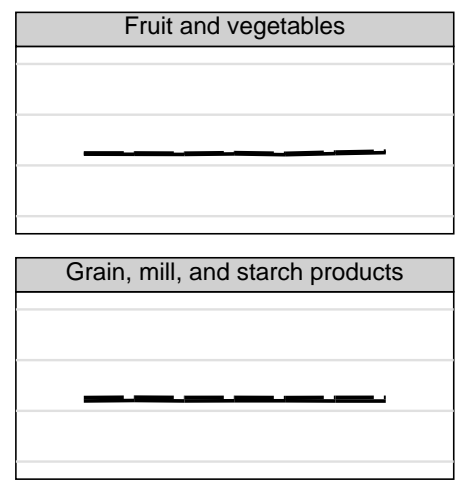

Other food products

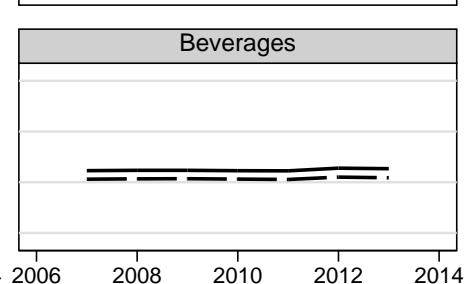

\section{Quantity TFP - - Revenue TFP}

Figure presents evolution of employment weighted average TFP estimated by the OP method with ACF correction for all firms in each of 9 food sub-industries in 2007-2013. The solid line represents quantity-based TFP, and the dashed line represents revenue-based TFP. We trimmed bottom 1 percent and top 1 percent of TFP values for each sub-industry.

\footnotetext{
${ }^{11}$ We also estimate those production functions by Levinsohn-Petrin (LP, Levinsohn and Petrin, 2003) method and using Ackerberg et al. (2015) corrections
} 


\section{Export and import}

A comprehensive transaction-level database of foreign trade in goods collected by Ukrainian Customs Service is used for generating our exports and imports variables. The dataset provides information on all export and import transactions at firm level. It contains information on value and quantity of trade, country of origin and country of destination, and the product classification code at four-digit level of the Harmonized System (HS4).

Figure 4 presents some stylized facts about exporters in food processing in Ukraine in 2007-2013. Ukraine joined WTO on May 16 2008. The timing of the WTO accession coincided with the beginning of the Great Recession, which led to a sharp decline in trade activities globally and in Ukraine. However, Ukrainian food industry recovered much faster than the rest of economy. Panel A presents values of trade statistics. The total export has been growing until 2008, when it reached 4.8 billion USD and then collapsed by 23 percent in 2009, before reaching a new record high of 7.6 billion USD in 2012 . Import of inputs by food processing firms during this period has been growing from 1.7 billion USD in 2007 to 2.8 billion USD in 2013. Panel B presents number of trading firms. Only about 10 percent of firms in food processing exported in 2007-2013. There was a substantial drop in the number of exporters between 2007 and 2013 from 579 to 514. The number of importers declined until 2009, when it recovered and reached 456 in 2013. Figure 5 reports median export and import prices in 2007-2013, which had reached the minimum in 2009 and have been steadily growing until 2012. In 2013 import prices continued to grow, while export prices had a small drop.

\section{NTMs and MFN tariffs}

\section{Import NTMs and MFN tariffs}

We construct import NTMs and MFN tariffs for each HS4 digit product line $h$ by aggregating corresponding NTMs and MFN tariffs for TS10 digit product lines as simple averages withing the product $h$ at time $t$. Section 2 describes it in more details. We define import SPS and mandatory certification measures as follows. SPS measure is calculate as

$$
S P S_{h t}=\frac{1}{4} \sum_{k_{1}} N T M_{h t}^{k_{1}}
$$


Figure 4: Exporters and importers in food processing in Ukraine in 2007-2013
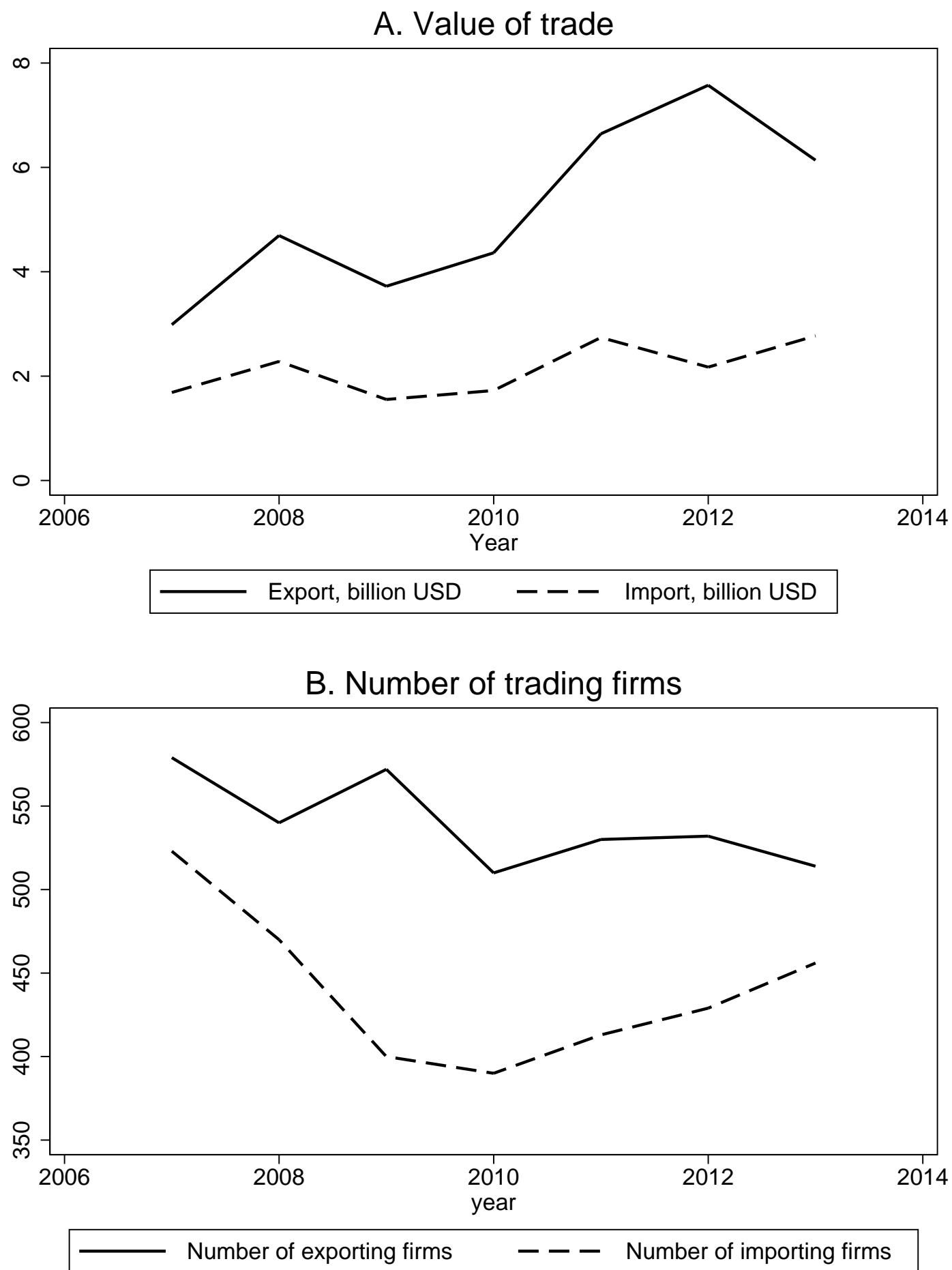

Data for this figure is from customs statistics in 2007-2013, limited by food-processing firms only. 
Figure 5: Median price of export and import in 2007-2013

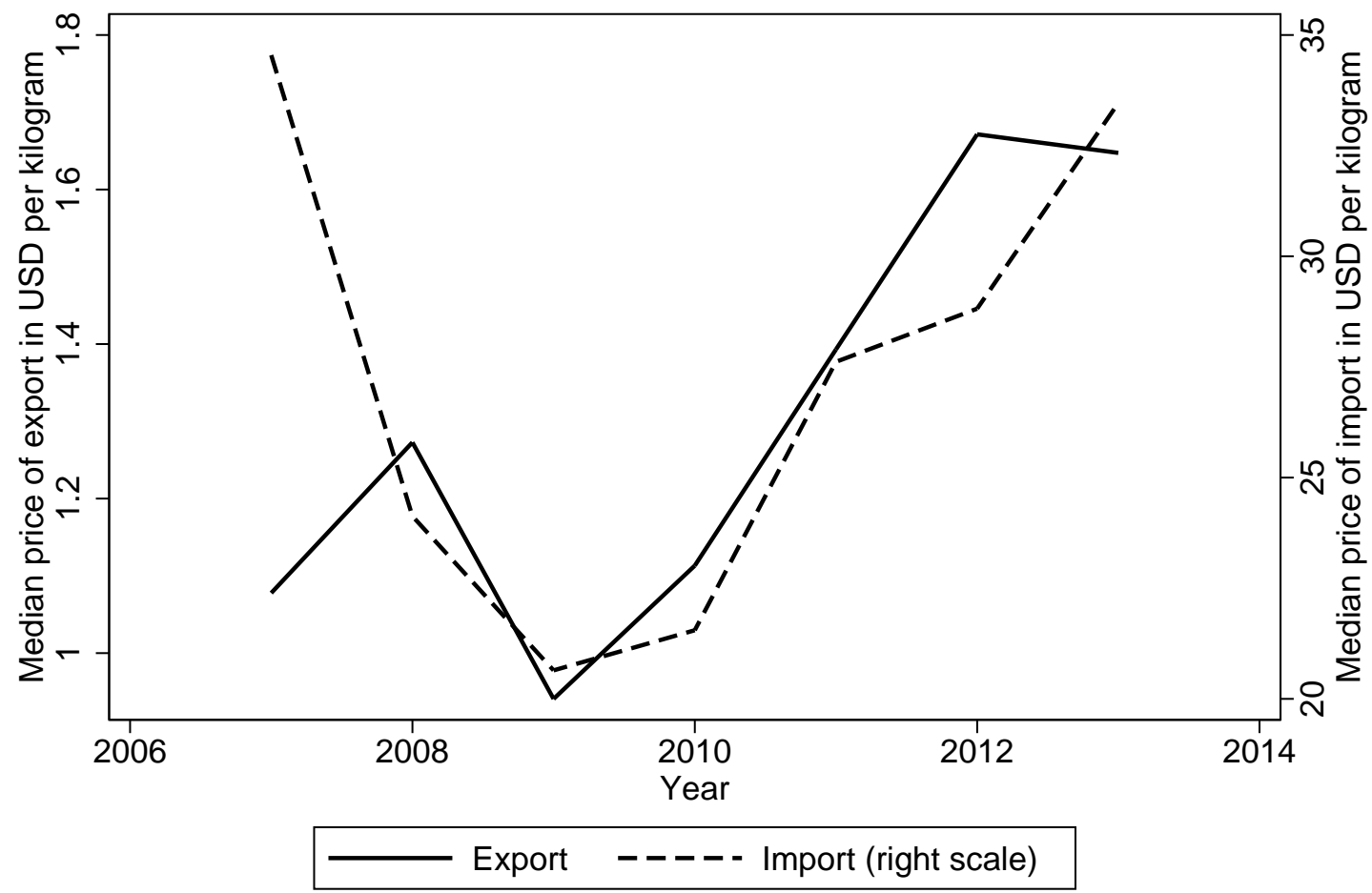

Data for this figure is from customs statistics in 2007-2013, restricted to food-processing firms only.

where $k_{1}=$ \{Veter, Ecol ,Sanit, Phyto\}, which captures the average level of SPS protection and allows us to evaluate the overall effect of SPS measures. It includes four types of NTMs excluding mandatory certifications. This measure captures extent of SPS checks within HS4 product category and intensity of checks by incorporating the measure of parallel inspections. If all product lines within an HS4 category are affected by only sanitary measures, it would take the value 0.25 . The drawback of this measure is its inability to measure actual costs incurred on producers by introducing SPS measures as it treats all measures equally. Also, it may be argued that introduction of new measures is not necessarily can be interpreted against trade liberalization, since it may represent the process of harmonization of local regulations with the WTO and EU regulations.

The mandatory certification measure, which capture how extensively it is used within HS4 product group, is given by

$$
\operatorname{Cert}_{h t}=N T M_{h t}^{k_{2}}
$$

where $k_{2}=\{$ Mandatory certification $\}$. Unlike SPS measures, which are almost exclusively applied 
to food products, mandatory certifications are applied to all product categories, including machinery and equipment.

\section{Input NTMs and MFN tariffs}

Following common practice in the literature (i.e. Amiti and Konings, 2007), for each HS 4 digit product line $h$ we construct input NTMs and input MFN tariffs that vary across HS 4 digit level and over time. The underlying assumptions is that all firms within a food export category $h$ use similar technologies and require similar inputs, hence they are subject to the same regulatory policy, which is exogenous from the firm's viewpoint. The fact that some firms use imported inputs, while others use local inputs reflects their endogenous decisions due to firm-level heterogeneity.

Input NTM of type $k$, where $k=\{$ Veter, Ecol, Sanit, Phyto, Cert $\}$ and input MFN tariff for HS 4 product line $h$ at time $t$ are computed as

$$
i n N T M_{h t}^{k}=\sum_{i} w_{h i}^{2003-2007} \times N T M_{i t}^{k}
$$

and

$$
i n M F N_{h t}=\sum_{i} w_{h i}^{2003-2007} \times M F N_{i t}
$$

where $N T M_{i t}^{k}$ is the share of TS10 product lines within the HS 4 product line $i$ that are covered by NTM of type $k$ at time $t$. $M F N_{i t}$ is a simple average MFN tariff rate, applied to all products imported

to Ukraine within the product line $i$ at time $t . w_{h i}^{2003-2007}$ is a weight, which equals to the share of the value of imported inputs from product line $i$ in the total imported inputs used in production of line $h$ exported by food processing firms over the period 2003-2007. We have chosen the period of 5 years prior to the time period that we will investigate in order to get stable weights that reflect technology of producing product $h$ using imported inputs.

We further calculate input SPS as given by

$$
i n S P S_{h t}=\frac{1}{4} \sum_{k_{1}} i n N T M_{h t}^{k_{1}}
$$

where $k_{1}=\{$ Veter, Ecol ,Sanit, Phyto $\}$, which captures the average level of input SPS protection 
and allows us to evaluate the overall effect of SPS on exports and quality. It includes four types of NTMs excluding mandatory certifications. The input certification measure is as follows

$$
\text { inCert }_{h t}=i n N T M_{h t}^{k_{2}}
$$

where $k_{2}=\{$ Mandatory certification $\}$.

\section{$5 \quad$ NTM, trade, and quality}

\subsection{Changes in trade policy and product characteristics}

To draw conclusions about the effect of trade policy on firm performance, a valid and important concern is endogeneity of the trade policy variables. Importers vary by their size, political connections, or degree of coordination and may influence trade policy decisions at the national level. As a result, more politically connected and economically "successful" industries may influence trade policy on intermediate inputs to their advantage.

Following Khandelwal and Topalova (2011), we check whether characteristics of importers can explain changes in trade policy over 2008-2013. Table 2 presents the results. Each cell represents a separate regression of a 5 year change in NTM or MFN tariff in 2008-2013 on the variable in the corresponding row. A unit of observation is an HS4 product-year, relevant variables are average output and employment, number of firms, Herfindahl-Hirschman Index (HHI) of concentration of firms importing within HS4 product. Results are presented with and without sub-industry fixed effects. None of the mentioned factors explain changes in the trade policy between 2008 and 2013: important characteristics of importers - their size, potential for coordination, and degree of concentration, measured as HHI are not able to explain changes in trade policy variables in any systematic way. It indicates lack of evidence that trade policy changes were driven by domestic firms lobbying. It also comes as no surprise given history of the Ukrainian WTO accession, which was the driving force of the changes in NTMs in after 2008. In fact, trade policy changes were primarily driven by major trading partners of Ukraine in the EU and US (Shepotylo and Vakhitov, 2015). 
Table 2: NTM and tariff liberalization and product characteristics

\begin{tabular}{|c|c|c|c|c|c|c|}
\hline & \multicolumn{2}{|c|}{ SPS } & \multicolumn{2}{|c|}{ Cert } & \multicolumn{2}{|c|}{$\mathrm{MFN}$} \\
\hline & (1) & $(2)$ & $(3)$ & $(4)$ & $(5)$ & (6) \\
\hline \multirow[t]{2}{*}{$\ln$ (Output) } & -.031 & -.032 & .018 & .028 & .003 & .001 \\
\hline & $(.020)$ & $(.023)$ & $(.097)$ & $(.11)$ & $(.0037)$ & $(.0042)$ \\
\hline \multirow[t]{2}{*}{$\ln ($ Employment $)$} & -.032 & -.031 & .064 & .086 & .000 & .001 \\
\hline & $(.025)$ & $(.027)$ & $(.12)$ & $(.13)$ & $(.0045)$ & $(.0049)$ \\
\hline \multirow[t]{2}{*}{$\ln$ (Number of firms) } & -.013 & -.017 & .029 & .041 & .000 & .000 \\
\hline & $(.012)$ & $(.013)$ & $(.056)$ & $(.061)$ & $(.0021)$ & $(.0023)$ \\
\hline \multirow[t]{2}{*}{ Industry concentration, $\mathrm{HHI}$} & .074 & .099 & .103 & .129 & -.016 & -.014 \\
\hline & $(.21)$ & $(.21)$ & $(.98)$ & $(1.00)$ & $(.038)$ & $(.038)$ \\
\hline Observations & 662 & 662 & 662 & 662 & 662 & 662 \\
\hline Sub-industry FE & No & Yes & No & Yes & No & Yes \\
\hline
\end{tabular}

Robust standard errors in parentheses.

Each cell represents a separate regression of a 5 year change in NTM or MFN tariff in 2008-2013 on the variable in the corresponding row. A unit of observation is an HS4 product, relevant variables are average output and employment of a firm, importing within HS4 product, number of firms and HHI index of concentration for firms importing HS4 product.

\subsection{NTMs and import of intermediate inputs}

We first investigate the impact of NTMs on imports of intermediate goods at extensive and intensive margins. ${ }^{12}$ Columns (1) and (2) of Table 3 present results for the extensive margin, measured as a binary variable which takes value 1 if firm $i$ import at time $t$ and zero otherwise. The unit of analysis is firm-year. Both regressions have firm fixed effects and standard errors, clustered at firm level. We also include year fixed effect to control for global shocks, including the 2008 Global Recession. According to the results, mandatory certifications negatively and significantly influence probability of importing, while SPS and MFN tariffs on imported inputs do not. In column (2) we additionally control for interactions between firm productivity in 2008 and NTMs, which are not significant. As expected, company size is positively associated with importing.

Columns (3)-(8) present results at intensive margins and their components, measured as the natural log of price in columns (3) and (4), natural log of quantity in (5) and (6), and natural log of value in columns (7) and (8). All models include firm level fixed effects; standard errors are clustered at firm level. We look at quantity $q$ in kilograms, value $v$ in USD, and price, proxied by the unit price, defined

\footnotetext{
${ }^{12}$ We assume that all goods that are imported by food processing firms are used in production. We further consider division of imported goods into capital, intermediate, and consumer goods.
} 
Table 3: Effect of NTMs on imports at extensive and intensive margins

\begin{tabular}{|c|c|c|c|c|c|c|c|c|}
\hline & \multicolumn{2}{|c|}{ Importer, Yes $=1$} & \multicolumn{2}{|c|}{ Price } & \multicolumn{2}{|c|}{ Quantity } & \multicolumn{2}{|c|}{ Value } \\
\hline & (1) & $(2)$ & (3) & $(4)$ & $(5)$ & (6) & (7) & (8) \\
\hline $\ln (1+\mathrm{SPS})$ & $\begin{array}{l}-.402 \\
(.344)\end{array}$ & $\begin{array}{l}-.299 \\
(.370)\end{array}$ & $\begin{array}{l}.110 \\
(.132)\end{array}$ & $\begin{array}{c}.067 \\
(.173)\end{array}$ & $\begin{array}{l}-.575^{*} \\
(.245)\end{array}$ & $\begin{array}{c}-.604^{+} \\
(.346)\end{array}$ & $\begin{array}{c}-.478^{*} \\
(.209)\end{array}$ & $\begin{array}{l}-.552^{*} \\
(.260)\end{array}$ \\
\hline $\ln (1+$ Cert $)$ & $\begin{array}{c}-.397^{* *} \\
(.122)\end{array}$ & $\begin{array}{c}-.580^{* *} \\
(.144)\end{array}$ & $\begin{array}{l}.063 \\
(.044)\end{array}$ & $\begin{array}{l}.093^{+} \\
(.049)\end{array}$ & $\begin{array}{l}-.134 \\
(.086)\end{array}$ & $\begin{array}{l}-.219^{*} \\
(.096)\end{array}$ & $\begin{array}{l}-.060 \\
(.071)\end{array}$ & $\begin{array}{l}-.111 \\
(.077)\end{array}$ \\
\hline $\ln (1+\mathrm{MFN})$ & $\begin{array}{l}-.230 \\
(.428)\end{array}$ & $\begin{array}{l}-.215 \\
(.453)\end{array}$ & $\begin{array}{l}1.066^{*} \\
(.480)\end{array}$ & $\begin{array}{l}1.127^{*} \\
(.484)\end{array}$ & $\begin{array}{c}-3.546^{+} \\
(1.811)\end{array}$ & $\begin{array}{c}-3.670^{*} \\
(1.843)\end{array}$ & $\begin{array}{l}-2.446 \\
(1.828)\end{array}$ & $\begin{array}{l}-2.508 \\
(1.847)\end{array}$ \\
\hline $\ln ($ Employment $)$ & $\begin{array}{l}.086^{* *} \\
(.012)\end{array}$ & $\begin{array}{l}.084^{* *} \\
(.013)\end{array}$ & $\begin{array}{l}.032 \\
(.068)\end{array}$ & $\begin{array}{c}.062 \\
(.075)\end{array}$ & $\begin{array}{l}.055 \\
(.115)\end{array}$ & $\begin{array}{l}.009 \\
(.129)\end{array}$ & $\begin{array}{l}.090 \\
(.082)\end{array}$ & $\begin{array}{l}.076 \\
(.091)\end{array}$ \\
\hline $\ln (1+\mathrm{SPS}) \times \mathrm{TFP}_{2008}$ & & $\begin{array}{l}.155 \\
(.103)\end{array}$ & & $\begin{array}{l}.340^{* *} \\
(.089)\end{array}$ & & $\begin{array}{c}-.772^{* *} \\
(.190)\end{array}$ & & $\begin{array}{c}-.433^{* *} \\
(.163)\end{array}$ \\
\hline $\ln (1+$ Cert $) \times \mathrm{TFP}_{2008}$ & & $\begin{array}{l}.057 \\
(.060)\end{array}$ & & $\begin{array}{l}-.028 \\
(.027)\end{array}$ & & $\begin{array}{l}.080 \\
(.055)\end{array}$ & & $\begin{array}{l}.050 \\
(.037)\end{array}$ \\
\hline $\begin{array}{l}\text { Observations } \\
R^{2}\end{array}$ & $\begin{array}{c}8326 \\
.02\end{array}$ & $\begin{array}{c}7039 \\
.02\end{array}$ & $\begin{array}{c}39946 \\
.73\end{array}$ & $\begin{array}{c}34131 \\
.73\end{array}$ & $\begin{array}{c}39960 \\
.71\end{array}$ & $\begin{array}{c}34145 \\
.70\end{array}$ & $\begin{array}{l}40016 \\
.52\end{array}$ & $\begin{array}{c}34201 \\
.52\end{array}$ \\
\hline
\end{tabular}

$+p<0.1,{ }^{*} p<0.05,{ }^{* *} p<0.01$ Standard errors are clustered by firms.

Models (1) and (2) are estimated by linear probability model. Models (3)-(8) are estmated by Stata module reghdfe developed by Guimaraes and Portugal (2010), which absorbs multiple levels of fixed effects. All models include firm fixed effects. Models (1) and (2) have year fixed effects. Models (3)-(8) include country-year, and product fixed effects. A unit of observation in (1) and (2) is firm-year. In models (3)-(8) unit of observation is firm-year-product-country. Sample is for 2008-2013.

as $p_{m, f h c t}=v_{m, f h c t} / q_{m, f h c t}$. A unit of analysis is a firm $f$, importing product $h$, from country $c$, at time $t$. Our main variables of interests are $S P S_{h t}$ and $C_{e r t}$, which measure intensity of various types of NTMs applied to a product of 4-digit HS category $h$ at time $t$ imposed by an importing country (Ukraine):

$$
\begin{aligned}
& \ln \left(p_{m, f h c t}\right)=\beta_{S P S} \ln \left(1+S P S_{h t}\right)+\beta_{C e r t} \ln \left(1+\text { Cert }_{h t}\right) \\
& +\beta_{M F N} \ln \left(1+M F N_{h t}\right)+X \gamma+D_{c t}+D_{f}+D_{h}+\varepsilon_{f h c t}
\end{aligned}
$$

Controls include firm size and TFP in 2008. Source market characteristics and bilateral trade costs are controlled for by including source country-time fixed effects, $D_{c t}$, which also capture global shocks to trade. $D_{h}$ is the product fixed effect that capture heterogeneity of various inputs and their differences in units of measurement (i.e. ingredients vs equipment). Finally, $\varepsilon_{h c t}$ is an error term.

Columns (3)-(4) of Table 3 display results with the natural log of price as the dependent variable. Column (3) reports the baseline regression with both SPS and Certification coefficients not significant. The MFN tariff is positive and significant, indicating that a one percent higher MFN tariff is associated with 1.07 percent higher unit price. In column (4) we also interact initial year productivity $\left(T F P_{2} 008\right)$ 
with SPS and Cert measures. By using productivity measures at the beginning of our sample, we deal with potential endogeneity concern of trade policy change having impact on productivity. We find a positive and significant coefficient of the interaction term between SPS and productivity, indicating that more SPS controls is associated with higher import prices for more productive firms. It may reflect the fact that more productive firms adjust quality of inputs more as a result of introduction of new SPS measures, which results in a higher price.

Table 3 also contains results of regressions with quantity (columns 5-6) and value of imports (columns 7-8) as dependent variables. We find that both SPS measures and MFN tariffs reduce quantity and value of imported inputs, while the effect of mandatory certifications is also negative, but insignificant. A one percent increase in SPS reduces quantity imported by 0.58 percent and value by 0.48 percent. The effect of an increase in SPS is more pronounced for more productive firms. A one percent increase in the MFN tariff reduces quantity imported by 3.5 percent and value by 2.4 percent. However, given the average MFN tariff of 4.7 percent in 2013 and the average input SPS of 20 percent, there is larger potential impact of full removal of SPS on imports.

Overall, these results confirm our prior expectations that non-tariff and tariff measures have a negative effect on probability of importing, quantity, and value of imported inputs, while the effect on their prices is positive, but not significant. Also, we find that more protectionist trade policy induces more productive firms to use relatively more expensive (and potentially of higher quality) imports at relatively lower quantities as compared to less productive firms.

We further look at different types of imports, according to broad economic categories - capital goods, intermediate goods, and consumer goods (BEC, Rev4), which have been mapped to HS4 digit product codes. ${ }^{13}$. Imported inputs are very heterogeneous - ranging from agricultural products to chemicals to machinery and equipment. Some of those are ingredients, other are packaging materials, and yet other are capital equipment. NTMs on capital equipment would restrict or make more expensive use of imported machines, having a larger impact on fixed costs of production and productivity, while NTMs on ingredients would more likely influence quality and variable costs. Figure 6 presents structure of imports of intermediate inputs by food processing firms in 2008. Imports of machinery and mechanical appliances (HS2 code 84 ) were slightly above 20 percent of total import in 2008. Two other important products, which are used in food processing and are not food ingredients, are plastic and articles thereof

\footnotetext{
${ }^{13}$ We use correspondence tables from https://unstats.un.org/unsd/trade/classifications/correspondence-tables.asp
} 
Figure 6: Structure of import of intermediate inputs in 2008

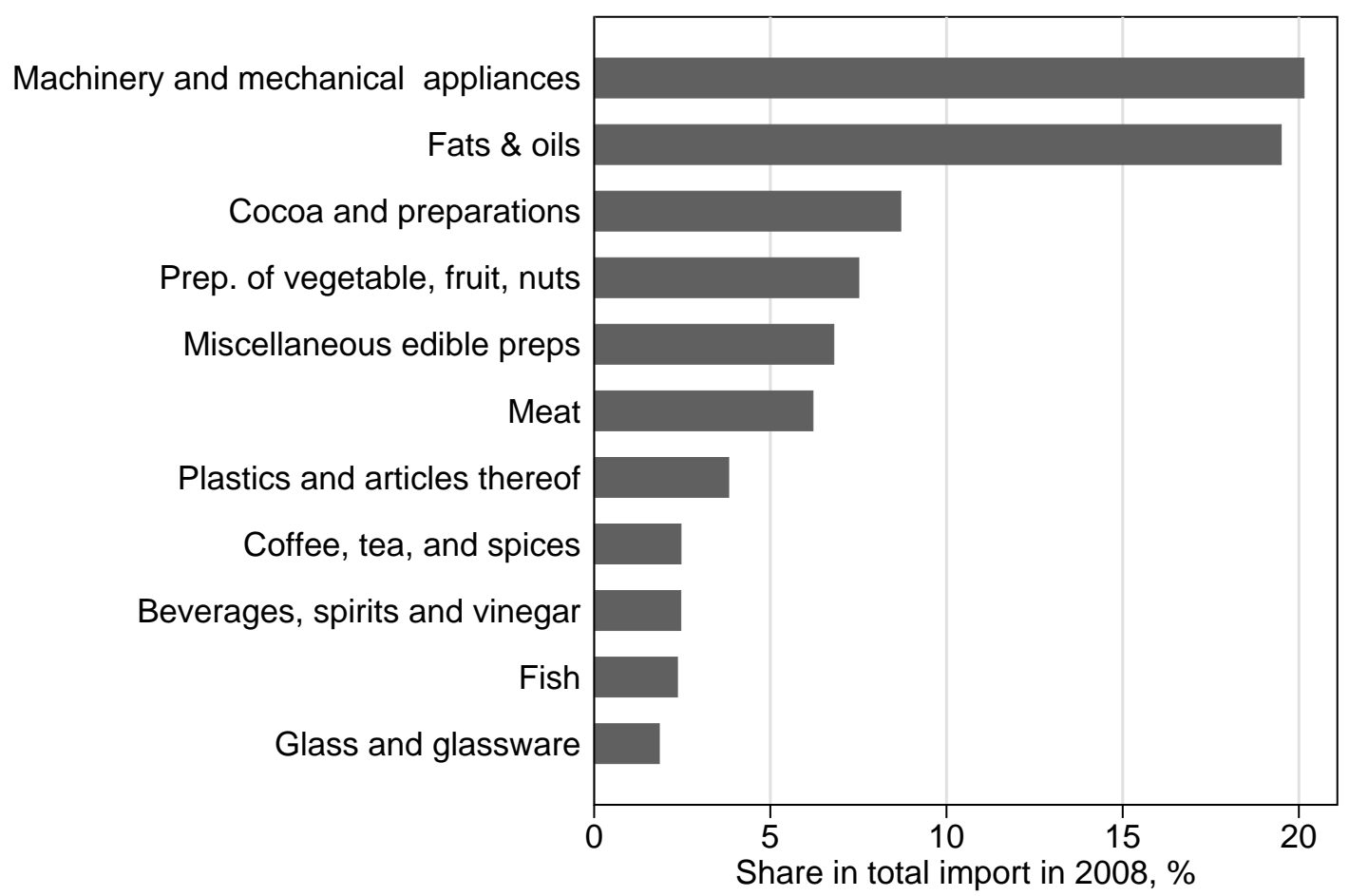

Structure of imported inputs by food processing firms in 2008. Only products with more than 1.5 percent of total import are shown.

(HS2 code 39) with 3.8 percent of total import and glass and glassware (HS2 code 70) with 1.8 percent. Among food related ingredients, imports of fats and oils (HS2 code 15) were almost 20 percent of total import, while import of cocoa and its preparations (HS2 code 18) was 9 percent of total imports.

We expect that intermediate goods are the most affected by SPS measures, since they are primarily used as ingredients in food production. Capital goods are not subject to SPS regulations, but they are affected by mandatory certifications. Consumer goods, on the other hand, are not necessarily used in production and we do not have any priors on how they are influenced by SPS and mandatory certifications.

Table 4 present results of the estimation of the effects at intensive margins, with the same model specification for 3 categories mentioned above. Mandatory certifications positively and significantly influence import prices. SPS measures, on the other hand, have a positive and significant effect on prices only for more productive firms. As expected, SPS measures negatively influence quantity of imported intermediate goods, while certifications have a negative impact on quantity of capital goods. The impact on value goes in the same direction, but is dampened by opposite effects on prices and 
Table 4: Effect of NTMs on imports by import categories

\begin{tabular}{|c|c|c|c|c|c|c|c|c|c|}
\hline & \multicolumn{3}{|c|}{ Price } & \multicolumn{3}{|c|}{ Quantity } & \multicolumn{3}{|c|}{ Value } \\
\hline & $\begin{array}{l}\text { (1) } \\
\text { Cap }\end{array}$ & $\begin{array}{c}(2) \\
\text { Intm }\end{array}$ & $\begin{array}{l}(3) \\
\text { Cons }\end{array}$ & $\begin{array}{l}(4) \\
\text { Cap }\end{array}$ & $\begin{array}{c}(5) \\
\text { Intm }\end{array}$ & $\begin{array}{c}(6) \\
\text { Cons }\end{array}$ & $\begin{array}{l}(7) \\
\text { Cap }\end{array}$ & $\begin{array}{c}(8) \\
\text { Intm }\end{array}$ & $\begin{array}{l}(9) \\
\text { Cons }\end{array}$ \\
\hline $\ln (1+\mathrm{SPS})$ & $\begin{array}{r}-.510^{+} \\
(.309)\end{array}$ & $\begin{array}{c}.377 \\
(.254)\end{array}$ & $\begin{array}{r}-.552^{+} \\
(.291)\end{array}$ & $\begin{array}{c}.864 \\
(.721)\end{array}$ & $\begin{array}{c}-1.013^{*} \\
(.484)\end{array}$ & $\begin{array}{l}.137 \\
(.499)\end{array}$ & $\begin{array}{c}.328 \\
(.581)\end{array}$ & $\begin{array}{r}-.629^{+} \\
(.325)\end{array}$ & $\begin{array}{l}-.416 \\
(.446)\end{array}$ \\
\hline $\ln (1+$ Cert $)$ & $\begin{array}{l}.187^{*} \\
(.092)\end{array}$ & $\begin{array}{l}.002 \\
(.078)\end{array}$ & $\begin{array}{l}.048 \\
(.063)\end{array}$ & $\begin{array}{c}-.525^{* *} \\
(.155)\end{array}$ & $\begin{array}{l}.021 \\
(.161)\end{array}$ & $\begin{array}{l}.063 \\
(.206)\end{array}$ & $\begin{array}{l}-.330^{*} \\
(.133)\end{array}$ & $\begin{array}{l}.032 \\
(.142)\end{array}$ & $\begin{array}{l}.137 \\
(.197)\end{array}$ \\
\hline $\begin{array}{l}\mathrm{TFP}_{2008} \\
\times \ln (1+\mathrm{SPS})\end{array}$ & $\begin{array}{c}.247 \\
(.184)\end{array}$ & $\begin{array}{l}.491^{* *} \\
(.133)\end{array}$ & $\begin{array}{l}.281^{*} \\
(.123)\end{array}$ & $\begin{array}{l}-.407 \\
(.408)\end{array}$ & $\begin{array}{c}-.820^{* *} \\
(.272)\end{array}$ & $\begin{array}{l}-.775^{*} \\
(.330)\end{array}$ & $\begin{array}{l}-.152 \\
(.286)\end{array}$ & $\begin{array}{l}-.337 \\
(.214)\end{array}$ & $\begin{array}{r}-.486^{+} \\
(.293)\end{array}$ \\
\hline $\begin{array}{l}\mathrm{TFP}_{2008} \\
\times \ln (1+\text { Cert })\end{array}$ & $\begin{array}{l}-.001 \\
(.030)\end{array}$ & $\begin{array}{l}-.056 \\
(.038)\end{array}$ & $\begin{array}{l}.011 \\
(.047)\end{array}$ & $\begin{array}{l}-.106 \\
(.071)\end{array}$ & $\begin{array}{l}.126^{+} \\
(.072)\end{array}$ & $\begin{array}{l}.164 \\
(.135)\end{array}$ & $\begin{array}{r}-.112^{+} \\
(.064)\end{array}$ & $\begin{array}{l}.068 \\
(.057)\end{array}$ & $\begin{array}{l}.177 \\
(.111)\end{array}$ \\
\hline $\ln (1+\mathrm{MFN})$ & $\begin{array}{l}4.551^{+} \\
(2.488)\end{array}$ & $\begin{array}{c}.143 \\
(1.325)\end{array}$ & $\begin{array}{c}1.092^{* *} \\
(.258)\end{array}$ & $\begin{array}{l}-5.774 \\
(4.131)\end{array}$ & $\begin{array}{c}-.051 \\
(2.354)\end{array}$ & $\begin{array}{l}-4.819^{*} \\
(2.234)\end{array}$ & $\begin{array}{l}-1.363 \\
(3.302)\end{array}$ & $\begin{array}{c}.135 \\
(1.952)\end{array}$ & $\begin{array}{l}-3.753 \\
(2.285)\end{array}$ \\
\hline $\ln ($ Employment $)$ & $\begin{array}{l}.177^{*} \\
(.087)\end{array}$ & $\begin{array}{l}.142 \\
(.089)\end{array}$ & $\begin{array}{l}-.051 \\
(.075)\end{array}$ & $\begin{array}{l}-.098 \\
(.144)\end{array}$ & $\begin{array}{l}-.132 \\
(.196)\end{array}$ & $\begin{array}{l}.003 \\
(.133)\end{array}$ & $\begin{array}{l}.085 \\
(.121)\end{array}$ & $\begin{array}{l}.008 \\
(.133)\end{array}$ & $\begin{array}{l}-.044 \\
(.112)\end{array}$ \\
\hline Observations & 8573 & 17785 & 7403 & 8576 & 17792 & 7406 & 8584 & 17830 & 7416 \\
\hline$R^{2}$ & .61 & .70 & .84 & .61 & .70 & .79 & .48 & .52 & .58 \\
\hline
\end{tabular}

$+p<0.1,{ }^{*} p<0.05,{ }^{* *} p<0.01$ Standard errors are clustered by firms.

Produts are categorized into capital, intermediate, and consumer goods based on clasification by broad economic categories (BEC Rev.4) All models include country-year, product and firm fixed effects. Models are estmated by Stata module reghdfe developed by Guimaraes and Portugal (2010), which absorbs multiple levels of fixed effects. Unit of observation is firm-year-product-country. Sample is for 2008-2013.

quantities. Still, certifications have a negative and significant impact on value of imported capital goods.

\subsection{NTMs and export}

We further analyse the effect of trade policy on exports of food processing firms in 2008-2013. We focus on the impact of NTMs in the upstream goods on export of HS4 products. First, we estimated a linear probability model of exporting to analyze the effect of input NTMs on extensive margins. Table 5 displays the results in columns (1) and (2). Both model specifications have firm fixed effects and year fixed effects. Standard errors are clustered at firm level.

We find that SPS measures and mandatory certifications on imported intermediate inputs have a strong negative impact on the probability of exporting. For the model (1), increase in SPS measure by a standard deviation reduces probability of exporting by 13 percent. Increase in mandatory certification by a standard deviation reduces probability of exporting by 6 percent. In column (2) we interact NTM measures with 2008 productivity. The interaction term is positive and significant for mandatory certification, indicating that more productive firms are less affected by mandatory certifications at extensive margins.

The next set of results in columns (3) and (4) of the table presents the effect of NTMs on export 
prices. We estimate the following regression model

$$
\begin{array}{r}
\ln \left(p_{\text {fhct }}\right)=\beta_{\text {inSPS }} \ln \left(1+i n S P S_{h t}\right)+\beta_{\text {inCert }} \ln \left(1+\text { inCert }_{h t}\right) \\
+\beta_{\text {inMFN }} \ln \left(1+i n M F N_{h t}\right)+X \gamma+D_{c t}+\epsilon_{f h c t}
\end{array}
$$

where $p_{f h c t}=v_{f h c t} / q_{f h c t}$ is the export unit price, $v$ is the value of export in USD, $q$ is the quantity of export in kilograms. Our main variables of interests are input trade policy measures (inSPS, inCert, and inMFN), which are computed according to equations $13-15 . X$ are set of controls, $D_{c t}$ are destination country-time fixed effects, and $\epsilon_{f h c t}$ is an error term.

Results in column (3) indicate that more frequent use of SPS measures on imported inputs results in higher export prices: one percent higher SPS is associated with 0.693 percent higher price. The result holds if we add an interaction term between productivity and SPS measure. Moreover, more productive firms experience a lower impact, perhaps indicating that the lower productivity firms should adjust their quality more if more SPS measures are imposed. The effects of mandatory certifications on export prices is opposite in sign and do not significantly vary with productivity. It may be the case that while regulations that control quality of ingredients makes export more expensive, controls on equipment reduce quality of the final product. We come back to this conjecture in the following sections when we look at the relationship between trade policy and quality.

In columns (5)-(6) and (7)-(8) we present results for quantity and value of exports, which indicate that SPS measures on imported inputs have a strong and significant negative effect on quantity of exports, which is consistent with the story of a negative impact of quality upgrading on quantity and value of exports under certain set of model parameters (see equation 7 ). A one percent increase in import SPS is associated with 2.9 percent decrease in quantity of exports. At the same time, mandatory certifications have a positive impact on quantity and overall value of exports.

We further investigate which types of SPS measures have influence on the export price. The results are presented in Table 6. SPS measures on imported intermediate inputs are associated with higher export prices. A one percent increase in sanitary measures is associated with 0.233 percent increase in the price of export. The effects of the rest of the SPS measures is not significant. It is important to note that veterinary and ecological measures are less frequent and are applied only to some product 
Table 5: Effect of NTMs on exports

\begin{tabular}{|c|c|c|c|c|c|c|c|c|}
\hline \multirow[b]{3}{*}{$\ln (1+\mathrm{inSPS})$} & \multicolumn{2}{|c|}{ Exporter, Yes $=1$} & \multicolumn{2}{|c|}{ Price } & \multicolumn{2}{|c|}{ Quantity } & \multicolumn{2}{|c|}{ Value } \\
\hline & (1) & (2) & (3) & (4) & (5) & (6) & (7) & (8) \\
\hline & $\begin{array}{c}-.549^{+} \\
(.320)\end{array}$ & $\begin{array}{l}-.705^{*} \\
(.346)\end{array}$ & $\begin{array}{l}.693^{*} \\
(.322)\end{array}$ & $\begin{array}{l}1.093^{*} \\
(.473)\end{array}$ & $\begin{array}{c}-2.900^{* *} \\
(1.005)\end{array}$ & $\begin{array}{l}-3.148^{*} \\
(1.289)\end{array}$ & $\begin{array}{c}-2.210^{* *} \\
(.850)\end{array}$ & $\begin{array}{l}-2.086^{*} \\
(1.032)\end{array}$ \\
\hline $\ln (1+$ inCert $)$ & $\begin{array}{c}-.221^{+} \\
(.122)\end{array}$ & $\begin{array}{c}-.490^{* *} \\
(.145)\end{array}$ & $\begin{array}{l}-.497^{*} \\
(.205)\end{array}$ & $\begin{array}{l}-.622^{*} \\
(.258)\end{array}$ & $\begin{array}{c}1.740^{* *} \\
(.469)\end{array}$ & $\begin{array}{l}2.180^{* *} \\
(.559)\end{array}$ & $\begin{array}{c}1.245^{* *} \\
(.413)\end{array}$ & $\begin{array}{c}1.569^{* *} \\
(.546)\end{array}$ \\
\hline $\ln (1+\mathrm{inMFN})$ & $\begin{array}{l}1.873^{* *} \\
(.435)\end{array}$ & $\begin{array}{l}2.321^{* *} \\
(.462)\end{array}$ & $\begin{array}{l}-.089 \\
(.537)\end{array}$ & $\begin{array}{l}-.168 \\
(.632)\end{array}$ & $\begin{array}{c}.306 \\
(1.399)\end{array}$ & $\begin{array}{c}.841 \\
(1.487)\end{array}$ & $\begin{array}{c}.234 \\
(1.469)\end{array}$ & $\begin{array}{c}.698 \\
(1.587)\end{array}$ \\
\hline $\ln$ (Employment) & $\begin{array}{l}.086^{* *} \\
(.012)\end{array}$ & $\begin{array}{l}.087^{* *} \\
(.013)\end{array}$ & $\begin{array}{l}-.032 \\
(.049)\end{array}$ & $\begin{array}{l}-.008 \\
(.057)\end{array}$ & $\begin{array}{l}.180^{+} \\
(.097)\end{array}$ & $\begin{array}{l}.150 \\
(.110)\end{array}$ & $\begin{array}{l}.147^{+} \\
(.087)\end{array}$ & $\begin{array}{l}.141 \\
(.097)\end{array}$ \\
\hline $\begin{array}{l}\ln (1+\text { inSPS }) \times \\
\mathrm{TFP}_{2008}\end{array}$ & & -.092 & & $-.531^{+}$ & & .453 & & -.050 \\
\hline $\begin{array}{l}\ln (1+\text { inCert }) \times \\
\mathrm{TFP}_{2008}\end{array}$ & & $\begin{array}{l}.207^{* *} \\
(.061)\end{array}$ & & $\begin{array}{c}.136 \\
(.088)\end{array}$ & & $\begin{array}{c}-.405^{* *} \\
(.132)\end{array}$ & & $\begin{array}{l}-.275 \\
(.178)\end{array}$ \\
\hline $\begin{array}{l}\text { Observations } \\
R^{2}\end{array}$ & $\begin{array}{c}8326 \\
.02\end{array}$ & $\begin{array}{c}7039 \\
.02\end{array}$ & $\begin{array}{c}31679 \\
.69\end{array}$ & $\begin{array}{c}26879 \\
.68\end{array}$ & $\begin{array}{c}31681 \\
.70\end{array}$ & $\begin{array}{c}26881 \\
.71\end{array}$ & $\begin{array}{c}31681 \\
.62\end{array}$ & $\begin{array}{c}26881 \\
.63\end{array}$ \\
\hline
\end{tabular}

$+p<0.1,{ }^{*} p<0.05,{ }^{* *} p<0.01$ Standard errors are clustered at firm level.

Models (1) and (2) are estimated by linear probability model. Models (3)-(8) are estmated by Stata module reghdfe developed by Guimaraes and Portugal (2010), which absorbs multiple levels of fixed effects. All models include firm fixed effects. Models (1) and (2) have year fixed effects. Models (3)-(8) include country-year, and product fixed effects. A unit of observation in (1) and (2) is firm-year. In models (3)-(8) unit of observation is firm-year-product-country. Sample is for 2008-2013.

categories. For ecological measures they are residues and waste from food (code 23), essential oils and resinoids; perfumery and cosmetics (code 33), miscellaneous chemical products (code 38), and lead and articles thereof (code 78). When all SPS measures included in column (5) of the table, the direction, size and statistical significance of the impact remains very similar. Mandatory certifications have negative and significant impact on export prices in all but one model specifications, which is consistent with the results in the previous section.

\subsection{NTM and quality}

Does higher price associated with more SPS controls reflect higher cost of production or higher quality? To address this question, we compute a firm-product quality measure that varies with time, following the methodology developed by Khandelwal et al. (2013), which has been also implemented to measure quality at firm level in Curzi et al. (2018). Quality is estimated from the following equation:

$$
\ln \left(q_{f h t}\right)+\sigma \ln \left(p_{f h t}\right)=\beta_{h}+\beta_{t}+\lambda_{f h t}
$$

where $\beta_{h}$ and $\beta_{t}$ are product and year fixed effects, $q_{f h t}$ is quantity of variety $h$ produced by firm 
Table 6: Effect of SPSs on exports by types of SPS

\begin{tabular}{|c|c|c|c|c|c|}
\hline & $\begin{array}{c}(1) \\
\ln \left(P_{\text {exp }}\right)\end{array}$ & $\begin{array}{c}(2) \\
\ln \left(P_{\exp }\right)\end{array}$ & $\begin{array}{c}(3) \\
\ln \left(P_{\text {exp }}\right)\end{array}$ & $\begin{array}{c}(4) \\
\ln \left(P_{\text {exp }}\right)\end{array}$ & $\begin{array}{c}(5) \\
\ln \left(P_{\text {exp }}\right)\end{array}$ \\
\hline $\ln \left(1+\mathrm{inSPS}_{\text {sanit }}\right)$ & $\begin{array}{l}.233^{* *} \\
(.075)\end{array}$ & & & & $\begin{array}{l}.243^{* *} \\
(.078)\end{array}$ \\
\hline $\ln \left(1+\mathrm{inSPS}_{\text {veter }}\right)$ & & $\begin{array}{l}.056 \\
(.23)\end{array}$ & & & $\begin{array}{l}.066 \\
.24)\end{array}$ \\
\hline $\ln \left(1+\operatorname{inSPS}_{\text {phyto }}\right)$ & & & $\begin{array}{l}-.265 \\
(.24)\end{array}$ & & $\begin{array}{l}-.356 \\
(.24)\end{array}$ \\
\hline $\ln \left(1+\right.$ inSPS $\left._{\text {ecolo }}\right)$ & & & & $\begin{array}{l}.159 \\
(.16)\end{array}$ & $\begin{array}{l}.062 \\
(.16)\end{array}$ \\
\hline $\ln (1+$ inCert $)$ & $\begin{array}{c}-.518^{*} \\
(.21)\end{array}$ & $\begin{array}{c}-.432^{*} \\
(.20)\end{array}$ & $\begin{array}{c}-.409^{+} \\
(.21)\end{array}$ & $\begin{array}{c}-.449^{*} \\
(.21)\end{array}$ & $\begin{array}{c}-.491^{*} \\
(.21)\end{array}$ \\
\hline $\ln (1+\mathrm{inMFN})$ & $\begin{array}{l}-.627 \\
(.75)\end{array}$ & $\begin{array}{l}-.595 \\
(.75)\end{array}$ & $\begin{array}{l}-.718 \\
(.75)\end{array}$ & $\begin{array}{l}-.557 \\
(.77)\end{array}$ & $\begin{array}{l}-.750 \\
(.77)\end{array}$ \\
\hline $\ln ($ Employment $)$ & $\begin{array}{l}-.021 \\
(.042)\end{array}$ & $\begin{array}{l}-.022 \\
(.042)\end{array}$ & $\begin{array}{l}-.021 \\
(.043)\end{array}$ & $\begin{array}{l}-.022 \\
(.042)\end{array}$ & $\begin{array}{l}-.020 \\
(.043)\end{array}$ \\
\hline Constant & $\begin{array}{l}.512^{+} \\
(.30)\end{array}$ & $\begin{array}{l}.608^{*} \\
(.30)\end{array}$ & $\begin{array}{l}.641^{*} \\
(.29)\end{array}$ & $\begin{array}{l}.605^{*} \\
(.30)\end{array}$ & $\begin{array}{l}.532^{+} \\
(.29)\end{array}$ \\
\hline Observations & 31631 & 31631 & 31631 & 31631 & 31631 \\
\hline$R^{2}$ & .78 & .78 & .78 & .78 & .78 \\
\hline
\end{tabular}

${ }^{+} p<0.1,{ }^{*} p<0.05,{ }^{* *} p<0.01$ Robust standard errors in parentheses.

All models have firm, product, and country-year fixed effects. Models are estmated by Stata module reghdfe developed by Guimaraes and Portugal (2010), which absorbs multiple levels of fixed effects.

$f$ at time $t$, and $p_{f h t}$ is its price. Firm's quality is computed as given by

$$
\text { Quality }_{f h t}=\frac{\hat{\lambda_{f h t}}}{\sigma_{h}-1}
$$

where $\sigma$ is elasticity of substitution for variety h is taken from Broda et al. (2006).

We further regress the estimated quality measure on NTM and tariffs, as well as on additional controls, using the following model specification

$$
\begin{array}{r}
\text { Quality }_{f h t}=\beta_{i n S P S} \ln \left(1+i n S P S_{h t}\right)+\beta_{\text {inCert }} \ln \left(1+i n C e r t_{h t}\right) \\
+\beta_{i n M F N} \ln \left(1+i n M F N_{h t}\right)+X \gamma+\epsilon_{h c t}
\end{array}
$$

Results are presented in Table 7. All models have year and product fixed effects to control for heterogeneity across products and global business cycles. Models (1) and (3)-(9) also include firm fixed effects. Standard errors are clustered at firm level. Quality is positively related to input SPS, which is consistent with our export price results in Table 5, columns (1)-(2). The effect of mandatory 
certifications on quality is negative and significant in most model specifications. Since SPS measures are applied almost exclusively to agricultural and food products, while mandatory certifications are applied to products in all product groups, including machinery and equipment, this result leads to a conclusion that while more SPS measures that target ingredients improve quality of final goods, the system of mandatory certification has a detrimental impact on quality through higher cost and import barriers on capital goods and equipment. It also points towards a policy recommendation, which is supported by the WTO and Ukrainian trading partners, to dismantle the outdated practice of mandatory certifications and move to SPS measures, harmonized with WTO and EU standards in order to improve quality of final goods in food industry and facilitate trade with Ukrainian trading partners.

In column (3) we add interaction terms between NTM variables with productivity. They are positive, but not significant. The positive sign for interaction between SPS and productivity is consistent with our results for imported inputs, where we found that more SPS have larger positive impact on import prices. In column (4) we measure quality using an alternative approach, implemented in Khandelwal (2010), having a similar result for SPS measures and not significant result for mandatory certifications. However, we should point out that this method requires good instruments for endogenous export prices, which in our case are not available since, unlike Khandelwal (2010), we look at firm level quality indicators for one country.

In columns (5)-(9) we break down the SPS measure by its components, separately estimating our model for different SPS measures. As our results indicate, sanitary measures are associated with better quality, while other measures do not have significant effects. It can be explain by the fact that sanitary measures are the most prominent part of SPS, having high frequency presence in all food sub-industries (see Figure 1), while others are relevant for only some sub-industries (i.e. Veterinary measures for meat and diary products) or are used very rarely (i.e. Ecological measures).

\section{Conclusion}

This paper explored the effect of NTMs on firms' imported inputs and exports. We have found that NTMs influence exports in two ways. First, more SPS regulations, sanitary measures in particular, induce firms to produce products of better quality. Second, NTMs increase costs and change composi- 
Table 7: Effect of NTMs on quality

\begin{tabular}{|c|c|c|c|c|c|c|c|c|c|}
\hline & $\begin{array}{c}(1) \\
\text { Base }\end{array}$ & $\begin{array}{c}(2) \\
+ \text { TFP2008 }\end{array}$ & $\begin{array}{c}(3) \\
+ \text { intract }\end{array}$ & $\begin{array}{c}(4) \\
\text { Alt. qual }\end{array}$ & $\begin{array}{c}(5) \\
\text { Sanit }\end{array}$ & $\begin{array}{c}(6) \\
\text { Veter }\end{array}$ & $\begin{array}{c}\text { (7) } \\
\text { Phyto }\end{array}$ & $\begin{array}{c}(8) \\
\text { Ecolo }\end{array}$ & $\begin{array}{l}\text { (9) } \\
\text { All }\end{array}$ \\
\hline $\ln (1+\mathrm{inSPS})$ & $\begin{array}{l}.602^{*} \\
(.21)\end{array}$ & $\begin{array}{l}.684^{*} \\
(.24)\end{array}$ & $\begin{array}{l}.921^{*} \\
(.32)\end{array}$ & $\begin{array}{c}1.378^{*} \\
(.44)\end{array}$ & & & & & \\
\hline $\ln (1+$ inCert $)$ & $\begin{array}{c}-.250^{*} \\
(.11)\end{array}$ & $\begin{array}{c}-.329^{*} \\
(.13)\end{array}$ & $\begin{array}{c}-.394^{*} \\
(.15)\end{array}$ & $\begin{array}{l}.226 \\
.18)\end{array}$ & $\begin{array}{c}-.240^{*} \\
(.11)\end{array}$ & $\begin{array}{c}-.168 \\
(.11)\end{array}$ & $\begin{array}{c}-.142 \\
(.11)\end{array}$ & $\begin{array}{r}-.181 \\
(.11)\end{array}$ & $\begin{array}{r}-.218^{+} \\
(.12)\end{array}$ \\
\hline $\ln (1+\mathrm{inMFN})$ & $\begin{array}{l}.134 \\
(.46)\end{array}$ & $\begin{array}{r}-.241 \\
(.50)\end{array}$ & $\begin{array}{r}-.178 \\
(.46)\end{array}$ & $\begin{array}{c}-2.473^{*} \\
(.65)\end{array}$ & $\begin{array}{l}.029 \\
(.46)\end{array}$ & $\begin{array}{l}.039 \\
(.45)\end{array}$ & $\begin{array}{l}-.061 \\
(.47)\end{array}$ & $\begin{array}{l}.065 \\
(.47)\end{array}$ & $\begin{array}{r}-.045 \\
(.47)\end{array}$ \\
\hline $\ln ($ Employment $)$ & $\begin{array}{l}.081^{*} \\
(.025)\end{array}$ & $\begin{array}{l}.092^{*} \\
(.021)\end{array}$ & $\begin{array}{l}.099^{*} \\
(.031)\end{array}$ & $\begin{array}{l}-.012 \\
(.033)\end{array}$ & $\begin{array}{l}.082^{*} \\
(.025)\end{array}$ & $\begin{array}{l}.081^{*} \\
(.025)\end{array}$ & $\begin{array}{l}.082^{*} \\
(.025)\end{array}$ & $\begin{array}{l}.081^{*} \\
(.025)\end{array}$ & $\begin{array}{l}.083^{*} \\
(.025)\end{array}$ \\
\hline $\mathrm{TFP}_{2008}$ & & $\begin{array}{l}.019 \\
(.019)\end{array}$ & $\begin{array}{l}.000 \\
(.)\end{array}$ & $\begin{array}{l}.000 \\
(.)\end{array}$ & & & & & \\
\hline $\mathrm{TFP}_{2008} \times \ln (1+\mathrm{inSPS})$ & & & $\begin{aligned}-.308 \\
(.21)\end{aligned}$ & $\begin{array}{l}.002 \\
(.29)\end{array}$ & & & & & \\
\hline $\mathrm{TFP}_{2008} \times \ln (1+$ inCert $)$ & & & $\begin{array}{l}.056 \\
(.058)\end{array}$ & $\begin{array}{c}-.112^{+} \\
(.063)\end{array}$ & & & & & \\
\hline $\ln (1+$ inSanit $)$ & & & & & $\begin{array}{l}.245^{*} \\
(.075)\end{array}$ & & & & $\begin{array}{l}.243^{*} \\
(.075)\end{array}$ \\
\hline $\ln (1+$ inVeter $)$ & & & & & & $\begin{array}{l}.054 \\
(.28)\end{array}$ & & & $\begin{array}{l}-.008 \\
(.28)\end{array}$ \\
\hline $\ln (1+$ inPhyto $)$ & & & & & & & $\begin{array}{c}-.259 \\
(.29)\end{array}$ & & $\begin{array}{l}-.244 \\
(.29)\end{array}$ \\
\hline $\ln (1+$ inEcolo $)$ & & & & & & & & $\begin{array}{l}.112 \\
(.17)\end{array}$ & $\begin{array}{l}.046 \\
(.16)\end{array}$ \\
\hline Constant & $\begin{array}{c}-.557^{*} \\
(.15)\end{array}$ & $\begin{array}{c}-.610^{*} \\
(.13)\end{array}$ & $\begin{array}{c}-.654^{*} \\
(.18)\end{array}$ & $\begin{array}{l}-.145 \\
(.20)\end{array}$ & $\begin{array}{c}-.548^{*} \\
(.15)\end{array}$ & $\begin{array}{c}-.443^{*} \\
(.15)\end{array}$ & $\begin{array}{c}-.409^{*} \\
(.15)\end{array}$ & $\begin{array}{c}-.443^{*} \\
(.15)\end{array}$ & $\begin{array}{c}-.523^{*} \\
(.16)\end{array}$ \\
\hline Observations & 7086 & 5791 & 5723 & 5636 & 7086 & 7086 & 7086 & 7086 & 7086 \\
\hline$R^{2}$ & .47 & .07 & .45 & .95 & .47 & .47 & .47 & .47 & .47 \\
\hline
\end{tabular}

$+p<0.1,{ }^{*} p<0.05$ Standard errors are clustered at firm level.

The dependent variable in models (1)-(3) and (5)-(8) is firm and product specific quality measure that varies over time, computed accoridng to Khandelwal et al. (2013). In model (4) quality computed accoring to an alternative procedure as in Khandelwal (2010) All models have year and product fixed effects. Models (1), (2)-(9) also have firm fixed effects. Models are estmated by Stata module reghdfe developed by Guimaraes and Portugal (2010), which absorbs multiple levels of fixed effects. Data are for 2008-2013. Products are HS2 codes $01-23$ only. 
tion of inputs from the upstream industries. The effects are highly heterogeneous across different types of NTMs and types of firms. While SPS measures on imported inputs induce quality upgrading and lower quantity of exports, outdated system of mandatory certifications work in the opposite direction. This last result is due to an outdated system of mandatory certifications in Ukraine and should be taken with caution, since it would not generalize for other countries. We also find evidence that SPS measures are associated with higher price of inputs for more productive firms.

These findings have important policy implications. First, all types of NTMs limit imports at extensive and intensive margins, which may have an adverse effect on productivity. Second, government policy directed towards safeguarding people health and safety would be more efficient if it targets quality and safety of ingredients rather than targets technological processes of production.

There are certain limitations that we did not address. First, our model assumes that quality is known. In reality, consumers do not have perfect information about quality, but they can infer it from past experience (country and firm reputation), quality and safety regulations, and regulations that inform consumers (i.e. mandatory labeling). Second, we assume that no variation in product quality exists within a firm across different markets. A firm can produce a variety of products with different levels of quality and serve different markets. We leave these issues for further research.

\section{References}

Ackerberg, D. A., Caves, K., and Frazer, G. (2015). Identification properties of recent production function estimators. Econometrica, 83(6):2411-2451.

Amiti, M. and Khandelwal, A. K. (2013). Import competition and quality upgrading. Review of Economics and Statistics, 95(2):476-490.

Amiti, M. and Konings, J. (2007). Trade Liberalization, Intermediate Inputs, and Productivity: Evidence from Indonesia. American Economic Review, 97(5):1611 - 1638.

Anders, S. M. and Caswell, J. A. (2009). Standards as barriers versus standards as catalysts: Assessing the impact of HACCP implementation on US seafood imports. American Journal of Agricultural Economics, 91(2):310-321. 
Bas, M. and Strauss-Kahn, V. (2015). Input-trade liberalization, export prices and quality upgrading. Journal of International Economics, 95(2):250-262.

Broda, C., Greenfield, J., and Weinstein, D. (2006). From groundnuts to globalization: A structural estimate of trade and growth. National Bureau of Economic Research, Working Paper No. w12512.

Crivelli, P. and Gröschl, J. (2016). The impact of sanitary and phytosanitary measures on market entry and trade flows. The World Economy, 39(3):444-473.

Crozet, M., Head, K., and Mayer, T. (2012). Quality Sorting and Trade: Firm-level Evidence for French Wine. Review of Economic Studies, 79(2):609-644.

Curzi, D., Raimondi, V., and Olper, A. (2015). Quality upgrading, competition and trade policy: evidence from the agri-food sector. European Review of Agricultural Economics, 42(2):239-267.

Curzi, D., Schuster, M., Maertens, M., and Olper, A. (2018). Standards, trade margins and product quality: Firm-level evidence from Peru. mimeo.

De Loecker, J., Goldberg, P. K., Khandelwal, A. K., and Pavcnik, N. (2016). Prices, markups, and trade reform. Econometrica, 84(2):445-510.

Disdier, A.-C., Fontagné, L., and Mimouni, M. (2008). The impact of regulations on agricultural trade: evidence from the SPS and TBT agreements. American Journal of Agricultural Economics, $90(2): 336-350$.

Eaton, J. and Kortum, S. (2002). Technology, geography, and trade. Econometrica, 70(5):1741-1779.

Fan, H., Li, Y. A., and Yeaple, S. R. (2015). Trade liberalization, quality, and export prices. Review of Economics and Statistics, 97(5):1033-1051.

Fan, H., Li, Y. A., and Yeaple, S. R. (2018). On the relationship between quality and productivity: Evidence from China's accession to the WTO. Journal of International Economics, 110:28-49.

Ferro, E., Otsuki, T., and Wilson, J. S. (2015). The effect of product standards on agricultural exports. Food Policy, 50(June):68-79.

Foster, L., Haltiwanger, J., and Syverson, C. (2008). Reallocation, firm turnover, and efficiency: Selection on productivity or profitability? American Economic Review, 98(1):394-425. 
Gardner, B. (2003). US Food Quality Standards: Fix for Market Failure or Costly Anachronism? American Journal of Agricultural Economics, 85(3):725-730.

Hallak, J. C. and Sivadasan, J. (2013). Product and process productivity: Implications for quality choice and conditional exporter premia. Journal of International Economics, 91(1):53-67.

Head, K. and Mayer, T. (2014). Gravity Equations: Workhorse, Toolkit, and Cookbook. Handbook of International Economics, 4:131.

Hoekman, B. and Nicita, A. (2011). Trade policy, trade costs, and developing country trade. World Development, 39(12):2069-2079.

IFC (2008). Technical Regulations in Ukraine: Ensuring Economic Development and Consumer Protection.

Khandelwal, A. (2010). The long and short (of) quality ladders. Review of Economic Studies, $77(4): 1450-1476$.

Khandelwal, A. and Topalova, P. (2011). Trade Liberalization and Firm Productivity: The Case of India. Review of Economics and Statistics, 93(3):995-1009.

Khandelwal, A. K., Schott, P. K., and Wei, S.-J. (2013). Trade liberalization and embedded institutional reform: evidence from chinese exporters. American Economic Review, 103(6):2169-95.

Levinsohn, J. and Petrin, A. (2003). Estimating Production Functions Using Inputs to Control for Unobservables. The Review of Economic Studies, 70(2):317-341.

Looi Kee, H., Nicita, A., and Olarreaga, M. (2009). Estimating trade restrictiveness indices. The Economic Journal, 119(534):172-199.

Manova, K. and Zhang, Z. (2012). Export prices across firms and destinations. Quarterly Journal of Economics, 127(1):379-436.

Melitz, M. J. (2003). The Impact of Trade on Intra-industry Reallocations and Aggregate Industry Productivity. Econometrica, 71(6):1695 - 1725.

Movchan, V. (2015). NTMs in Ukraine: can we talk about liberalization? mimeo. 
Olley, G. S. and Pakes, A. (1996). The Dynamics of Productivity in the Telecommunications Equipment Industry. Econometrica, 64(6):1263 - 1297.

Olper, A., Curzi, D., and Raimondi, V. (2017). Imported intermediate inputs and firms productivity growth: evidence from the food industry. Journal of Agricultural Economics, 68(1):280-300.

Otsuki, T., Wilson, J. S., and Sewadeh, M. (2001). Saving two in a billion:: quantifying the trade effect of European food safety standards on African exports. Food Policy, 26(5):495-514.

Shepotylo, O. and Vakhitov, V. (2015). Services Liberalization and Productivity of Manufacturing Firms. Economics of Transition, 23(1):1-44.

Sunding, D. L. (2003). The role for government in differentiated product markets: Looking to economic theory. American Journal of Agricultural Economics, 85(3):720-724.

Xiong, B. and Beghin, J. (2014). Disentangling demand-enhancing and trade-cost effects of maximum residue regulations. Economic Inquiry, 52(3):1190-1203. 


\section{A Online appendix for Non-tariff measures, quality, and exporting: evidence from microdata in food processing in Ukraine}

\section{A.1 Exporter decision}

Solving for the domestic price as a function of productivity yields free on board (FOB) price

$$
p(\varphi)=\left(\frac{\sigma-1}{\sigma}\right)^{\frac{\sigma-1+\beta-\alpha}{\rho}}\left(\frac{\varphi}{\kappa}\right)^{\frac{\sigma-1-\alpha}{\rho}}\left(\frac{1-\beta}{\alpha f} W\left(I_{x}\right)\right)^{\frac{\beta}{\rho}}
$$

Due to our assumption that firms do not differentiate quality by markets, domestic price depend on aggregate demand in Foreign, because if the economic situation in Foreign improves, domestic exporters upgrade quality, which translates into higher domestic prices. Interestingly, more productive firms charge higher price only when $\sigma-1>\alpha$.

A firm chooses the quality level such that

$$
f \lambda^{\alpha}=\frac{1-\beta}{\alpha} \times \frac{\sigma-1}{\sigma} r
$$

Increasing fixed cost due to higher quality at optimum are balanced by higher revenue caused by better quality. Using (19), profit of non-exporter is given by

$$
\pi_{d}=\frac{r}{\sigma}-F(\lambda)=\frac{\rho r}{\alpha \sigma}-F_{0}
$$

It is convenient to express domestic revenue and profit as

$$
r_{d}=\left(\frac{\varphi}{\kappa}\right)^{(\sigma-1) \frac{\alpha}{\rho}} \times H \times\left(\frac{R}{P^{1-\sigma}}\right)^{\frac{\alpha}{\rho}}
$$

and

$$
\pi_{d}(\varphi)=\left(\frac{\varphi}{\kappa}\right)^{(\sigma-1) \frac{\alpha}{\rho}} \times f^{\frac{\rho-\alpha}{\rho}} \times J \times\left(\frac{R}{P^{1-\sigma}}\right)^{\frac{\alpha}{\rho}}-F_{0}
$$

where $H=\left(\frac{\sigma-1}{\sigma}\right)^{\frac{\alpha \sigma-\rho}{\rho}} \times\left(\frac{1-\beta}{f \alpha}\right)^{\frac{\alpha-\rho}{\rho}}$.

In the spirit of Melitz (2003), we determine a domestic cut-off that separates producing, nonexporting firms from exiting firms. We define the cut-off by finding $\varphi_{d}: \pi_{d}\left(\varphi_{d}\right)=0$, which is 
expressed as

$$
\varphi_{d}=\frac{\kappa f^{\frac{1-\beta}{\alpha}}}{P}\left(\frac{F_{0}}{J}\right)^{\frac{\rho}{\alpha(\sigma-1)}}(R)^{\frac{1}{1-\sigma}}
$$

where $J \equiv\left(\frac{\sigma-1}{\sigma}\right)^{\frac{\alpha \sigma}{\rho}}\left(\frac{1-\beta}{\alpha}\right)^{\frac{\alpha}{\rho}}\left(\frac{\rho}{\alpha-\rho}\right)$.

\section{Exporter decision}

For an exporting firm $r_{x}=\left(\frac{\varphi}{\kappa}\right)^{(\sigma-1) \frac{\alpha}{\rho}} \times H \times\left(W\left(I_{x}=1\right)\right)^{\frac{\alpha}{\rho}}$ and profit level is $\pi_{x}(\varphi)=\left(\frac{\varphi}{\kappa}\right)^{(\sigma-1) \frac{\alpha}{\rho}} \times$ $f^{\frac{\rho-\alpha}{\rho}} \times J \times\left(W\left(I_{x}=1\right)\right)^{\frac{\alpha}{\rho}}-F_{0}-f_{x}$. We define the exporting threshold as $\varphi_{\text {exp }}: \pi_{d}\left(\varphi_{\text {exp }}\right)=\pi_{x}\left(\varphi_{\text {exp }}\right)$, which is determined as

$$
\varphi_{\text {exp }}=k\left\{\frac{f_{x}}{f^{\frac{\rho-\alpha}{\rho}} \times J \times\left(W\left(I_{x}=1\right)^{\frac{\alpha}{\rho}}-W\left(I_{x}=0\right)^{\frac{\alpha}{\rho}}\right)}\right\}^{\frac{\rho}{(\sigma-1) \alpha}}
$$

To ensure that $\varphi_{\exp }>\varphi_{d}$, it is required that

$$
f_{x}>F_{0}\left[\left(1+\tau^{1-\sigma} \frac{R^{*} P^{*(\sigma-1)}}{R P^{(\sigma-1)}}\right)^{\frac{\alpha}{\rho}}-1\right]
$$

\section{A.2 Minimum quality restriction}

Suppose that the domestic government sets a minimum quality restriction, $\lambda_{N T M}$. We rule out the trivial case when the constraint is not binding for any firm and consider the case when $\lambda^{*}\left(\varphi_{d}\right)<$ $\lambda_{N T M}<\lambda^{*}\left(\varphi_{\text {exp }}\right)$. Keeping the industry aggregates constant, this policy does not change behavior of 'exitors', local firms from Region 4, and exporters. However, for firms located in Regions II and III there is a dilemma - either to exit the industry or to upgrade their quality to $\lambda_{N T M}$.

We define $\varphi_{N T M}^{*}: \lambda^{*}\left(\varphi_{N T M}^{*}\right)=\lambda_{N T M}$. Consider a firm from regions II or III. It finds it optimal to upgrade if

$$
\pi_{c}(\varphi)=\frac{r\left(\varphi, \lambda_{N T M}\right)}{\sigma}-F\left(\lambda_{N T M}\right) \geq 0
$$

$\pi_{c}$ monotonically increases with productivity. Moreover, $\pi_{c}\left(\varphi_{d}\right) \leq \pi_{d}\left(\varphi_{d}, \lambda^{*}\left(\varphi_{d}\right)\right)=0<\pi_{d}\left(\varphi_{N T M}^{*}, \lambda_{N T M}\right)=$ $\pi_{c}\left(\varphi_{N T M}\right)$. Therefore, $\exists \varphi_{N T M}: \pi_{c}\left(\varphi_{N T M}\right)=0$ such that all firms with $\varphi<\varphi_{N T M}$ exit and all firms with $\varphi_{N T M}<\varphi<\varphi_{N T M}^{*}$ upgrade their quality to the level of $\lambda_{N T M}$. Solving for the productivity 
threshold yields

$$
\varphi_{N T M}=\frac{\sigma}{(\sigma-1)} \frac{k}{P} \frac{\lambda_{N T M}^{\beta-1} R^{\frac{1}{1-\sigma}}}{\left(\sigma F_{0}+\sigma f \lambda_{N T M}^{\alpha}\right)^{\frac{1}{1-\sigma}}}
$$

\section{A.3 Revenue based and quantity based estimates of productivity}

Foster et al. (2008) identified a common problem in empirical research when productivity estimation is based on revenue $r=p \times q$. A standard procedure of estimating revenue-based production function by Olley and Pakes (1996) (OP) leads to TFP capturing confounding effects of prices, quality, and quantity.

We implement the quantity-based OP estimation of the production function, which is given by

$$
q=\exp (\omega) k^{\alpha_{k}} h^{\alpha_{h}} m^{\alpha_{m}}
$$

which differs from the revenue-based production function

$$
R=\exp (\omega) k^{\gamma_{k}} h^{\gamma_{h}} m^{\gamma_{m}}
$$

Consider a multi-product firm with the set of outputs and prices $\left\{p_{i}, q_{i}\right\}, i=1, \ldots, N$. The firm produces goods that are substitutes with constant elasticity of substitution $\sigma$. We define a firm-level price index

$$
P^{1-\sigma}=\sum w_{i} p_{i}^{1-\sigma}
$$

where $w_{i}=\frac{p_{i} q_{i}}{R} \cdot{ }^{14}$ We further define quantity of the output for a multi-product firm as $q=r / P$.

We estimate (21) and (22) by OP with correction suggested in Ackerberg et al. (2015). ${ }^{15}$ We did this to see whether the effect of NTMs on TFP depends on the sample used for estimating productivity.

Table 8 presents point estimates of the coefficients of production function. Coefficients of the revenue-based production function are reported on the left side of the table, while coefficients of the quantity-based production function are reported on the right side of the table.

\footnotetext{
${ }^{14}$ We take $\sigma=5$ for our main result, as it is common in the literature (Head and Mayer, 2014). We also perform robustness checks with other values of $\sigma$, which do not change our conclusions. The results are available upon request.

${ }^{15}$ We also estimate those production functions by Levinsohn-Petrin (LP, Levinsohn and Petrin, 2003) method and using Ackerberg et al. (2015) corrections
} 
Table 8: TFP Estimation by Olley-Pakes

\begin{tabular}{|c|c|c|c|c|c|c|c|c|}
\hline \multirow[b]{2}{*}{ Industry } & \multicolumn{4}{|c|}{ Revenue Productivity } & \multicolumn{4}{|c|}{ Quantity Productivity } \\
\hline & $\ln k$ & $\ln h$ & $\ln m$ & $\mathrm{~N}$ & $\ln k$ & $\ln h$ & $\ln m$ & $\mathrm{~N}$ \\
\hline Meat products & $\begin{array}{l}.068 \\
(.034)\end{array}$ & $\begin{array}{l}.181 \\
(.045)\end{array}$ & $\begin{array}{l}.736 \\
(.044)\end{array}$ & 2255 & $\begin{array}{l}.088 \\
(.057)\end{array}$ & $\begin{array}{l}.388 \\
(.078)\end{array}$ & $\begin{array}{l}.638 \\
(.069)\end{array}$ & 1501 \\
\hline Fish products & $\begin{array}{l}.212 \\
(.145)\end{array}$ & $\begin{array}{c}.3 \\
(.093)\end{array}$ & $\begin{array}{l}.546 \\
(.09)\end{array}$ & 421 & $\begin{array}{l}.087 \\
(.223)\end{array}$ & $\begin{array}{l}.358 \\
(.212)\end{array}$ & $\begin{array}{l}.608 \\
(.13)\end{array}$ & 291 \\
\hline Fruit and vegetables & $\begin{array}{l}.005 \\
(.052)\end{array}$ & $\begin{array}{l}.248 \\
(.053)\end{array}$ & $\begin{array}{l}.689 \\
(.062)\end{array}$ & 982 & $\begin{array}{l}-.128 \\
(.248)\end{array}$ & $\begin{array}{l}.403 \\
(.158)\end{array}$ & $\begin{array}{l}.835 \\
(.092)\end{array}$ & 637 \\
\hline $\begin{array}{l}\text { Vegetable and animal } \\
\text { oils and fats }\end{array}$ & $\begin{array}{l}.006 \\
(.068)\end{array}$ & $\begin{array}{c}.1 \\
(.073)\end{array}$ & $\begin{array}{l}.671 \\
(.057)\end{array}$ & 724 & $\begin{array}{c}.031 \\
(.106)\end{array}$ & $\begin{array}{l}.555 \\
(.154)\end{array}$ & $\begin{array}{l}.634 \\
(.058)\end{array}$ & 421 \\
\hline Dairy products & $\begin{array}{l}.055 \\
(.026)\end{array}$ & $\begin{array}{l}.357 \\
(.056)\end{array}$ & $\begin{array}{l}.599 \\
(.044)\end{array}$ & 2888 & $\begin{array}{l}-.059 \\
(.071)\end{array}$ & $\begin{array}{l}.188 \\
(.115)\end{array}$ & $\begin{array}{l}.856 \\
(.076)\end{array}$ & 1908 \\
\hline $\begin{array}{l}\text { Grain, mill products, } \\
\text { starch products }\end{array}$ & $\begin{array}{l}.015 \\
(.024)\end{array}$ & $\begin{array}{l}.189 \\
(.03)\end{array}$ & $\begin{array}{l}.684 \\
(.028)\end{array}$ & 5124 & $\begin{array}{l}-.018 \\
(.037)\end{array}$ & $\begin{array}{c}-.1 \\
(.055)\end{array}$ & $\begin{array}{l}.845 \\
(.049)\end{array}$ & 3592 \\
\hline Prepared animal feeds & $\begin{array}{l}.023 \\
(.065)\end{array}$ & $\begin{array}{l}.137 \\
(.056)\end{array}$ & $\begin{array}{l}.741 \\
(.04)\end{array}$ & 522 & $\begin{array}{l}-.117 \\
(.106)\end{array}$ & $\begin{array}{l}.568 \\
(.126)\end{array}$ & $\begin{array}{l}.616 \\
(.064)\end{array}$ & 319 \\
\hline Other food products & $\begin{array}{l}.025 \\
(.034)\end{array}$ & $\begin{array}{l}.174 \\
(.039)\end{array}$ & $\begin{array}{l}.572 \\
(.036)\end{array}$ & 2400 & $\begin{array}{l}.037 \\
(.194)\end{array}$ & $\begin{array}{l}.342 \\
(.238)\end{array}$ & $\begin{array}{c}.97 \\
(.161)\end{array}$ & 1446 \\
\hline Beverages & $\begin{array}{l}.018 \\
(.034)\end{array}$ & $\begin{array}{l}.223 \\
(.041)\end{array}$ & $\begin{array}{l}.814 \\
(.025)\end{array}$ & 3102 & $\begin{array}{l}.144 \\
(.23)\end{array}$ & $\begin{array}{l}.202 \\
(.222)\end{array}$ & $\begin{array}{l}.876 \\
(.093)\end{array}$ & 1759 \\
\hline
\end{tabular}

Production function is estimated by Olley and Pakes (1996) with corrections, following Ackerberg et al. (2015). 
A.4 Data and variable description 
Table 9: Variables used for production function estimation

\begin{tabular}{lll}
\hline Variable & Description & Source \\
\hline Output-revenue & Total sales after excise tax and other indirect taxes & $\begin{array}{l}\text { Individual firm annual Income } \\
\text { statements, 2003-2013 }\end{array}$ \\
\hline $\begin{array}{l}\text { Output- } \\
\text { quantity }\end{array}$ & $\begin{array}{l}\text { Total revenue divided by the price index, which is } \\
\text { composed from physical outputs across all product } \\
\text { categories produced by a firm in a given year }\end{array}$ & $\begin{array}{l}\text { Annual manufacturing", 2004-2013 } \\
\text { matent }\end{array}$ \\
\hline Materials & $\begin{array}{l}\text { Firm's expenditures on materials, supplies, and util- } \\
\text { ities. }\end{array}$ & $\begin{array}{l}\text { Individual firm annual Income } \\
\text { statements, 2003-2013 }\end{array}$ \\
\hline Employment & $\begin{array}{l}\text { Full-time equivalent of the labor force, calculated as } \\
\text { the average number of employees weighted by their } \\
\text { time involvement. }\end{array}$ & $\begin{array}{l}\text { Supplement to annual balance } \\
\text { sheets, 2003-2013 }\end{array}$ \\
\hline Capital & End-of-year value of fixed assets & $\begin{array}{l}\text { Annual balance sheets, 2003- } \\
\text { 2013 }\end{array}$ \\
\hline $\begin{array}{lll}\text { Investment } & \text { Total annual investments in fixed assets } & \text { Enterprise performance state- } \\
\text { ment, 2003-2013 }\end{array}$ \\
\hline Deflators & & State Statsitcs Service \\
\hline $\begin{array}{l}\text { For capital, cap- } \\
\text { ital investments }\end{array}$ & Producer price index & State Statsitcs Service \\
\hline For output & Sector-specific price index & State Statsitcs Service \\
\hline material & Consumer price index & \\
\hline
\end{tabular}


Table 10: Variables used in Empirical Analysis

\begin{tabular}{lll}
\hline$N T M_{\text {Sanit }}$, & The share of 10-digit imports lines affected by, corre- & Law of Ukraine on Veterinary \\
$N T M_{\text {Veter }}$, & spondingly, sanitary, veterinary, phytosanitary and & Medicine; \\
$N T M_{\text {Phyto }}$, & ecological NTM in the aggregated 4-digit imports & Law of Ukraine on Food Safety; \\
$N T M_{\text {Ecolo }}$ & line. & Law of Ukraine on Quarantine \\
& & of Plants; \\
& Law of Ukraine on Environment \\
& Protection \\
\hline
\end{tabular}

SPS, Average of the four 4-digit NTM measures defined
$\ln (1+S P S) \quad$ above: $S P S_{h t}=\frac{1}{4} \sum_{k_{1}} N T M_{h t}^{k_{1}}$

Cert, The share of 10-digit imports lines affected by $\ln (1+$ Cert $) \quad$ mandatory certification in the aggregated 4 -digit imports line.

Orders of State Committee on Technical Regulation and Consumer Policy on the List of Products of Mandatory Certification; Orders of State Standardization Office on List of Products of Mandatory Certification

\begin{tabular}{|c|c|c|}
\hline $\begin{array}{l}\mathrm{MFN} \\
\ln (1+M F N)\end{array}$ & $\begin{array}{l}\text { The share of } 10 \text {-digit imports lines affected Most } \\
\text { Favourable Nation Tariifs in the aggregated 4-digit } \\
\text { imports line; calculated for each firm importing items } \\
\text { from a particular } 4 \text {-digit line. }\end{array}$ & $\begin{array}{l}\text { Trade-weighted average most } \\
\text { favoured nation (MFN) tariff } \\
\text { from the World Bank databank. }\end{array}$ \\
\hline$T F P_{2008}$ & $\begin{array}{l}\text { Total factor productivity in } 2008 \text {, estimated at the } \\
\text { firm level }\end{array}$ & \\
\hline$i n N T M_{h t}^{k}$ & $\begin{array}{l}\text { inNT } M_{h t}^{k}=\sum_{i} w_{h i}^{2003-2007} \times N T M_{i t}^{k} ; w_{h i}^{2003-2007} \text { is a } \\
\text { weight, which equals to the share of the } \\
\text { value of imported inputs from product line i in the } \\
\text { total imported inputs used in production of line } \\
h \text { exported by food processing firms over the period } \\
2003-2007 \text {. }\end{array}$ & \\
\hline inMFN $N_{h t}$ & $\begin{array}{l}i n M F N_{h t}=\sum_{i} w_{h i}^{2003-2007} \times M F N_{i t} ; w_{h i}^{2003-2007} \\
\text { is the same as define above }\end{array}$ & \\
\hline$i n S P S_{h t}$ & $i n S P S_{h t}=\frac{1}{4} \sum_{k_{1}} i n N T M_{h t}^{k_{1}}$ & \\
\hline inCert $_{h t}$ & inNTM $M_{h t}^{C e r t}$ & \\
\hline Value & $\begin{array}{l}\text { Logarithm of total value, in USD, for the firm } f \text {, } \\
\text { importing product } h \text {, from country } c \text {, at time } t \text {. }\end{array}$ & Customs declarations \\
\hline Quantity & Logarithm of quantity in kilograms & Customs declarations \\
\hline Price & Logarithm of price in USD, proxied by unit price & Customs declarations \\
\hline$P_{\text {exp }}, \ln \left(P_{\text {exp }}\right)$ & Price of exports & \\
\hline
\end{tabular}

